\title{
BİR KÜLTÜRÜN DÖNÜȘÜMÜ: “POSTTÜRKÜ"
}

\author{
Transformation of a Culture: Posttürkü
}

Mahir MAK *

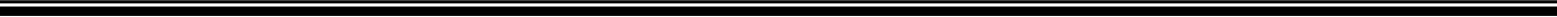

ÖZ

Cumhuriyet dönemi müzik politikaları ulus-devlet, homojen kültür, standart dil kavramları gibi bir dizi arayış içindedir. TRT bu politikaların uygulanabilirliği ve devamlılığ 1 noktasında ayrıcalıklı bir yere sahiptir. Bilhassa, Anadolu'nun geleneksel müzik kültürünün taşınıp aktarılması yönündeki çabaları oldukça anlamlıdır. Bünyesinde yer verdiği müzik programları, korolar ve derleme çalışmaları bu çabaların birer göstergesi olarak düşünülmelidir. Ancak, taşımış olduğu politik misyonu Anadolu'nun geleneksel müzik haritasını önemli derecede değiştirmiştir. Yanı sıra, TRT, müzik eğitimi veren okullar, konservatuvarlar, belediye ve bakanlık bünyesinde kurulan geleneksel müzik icra eden toplulukların da referans gördüğü bir kurum olması hasebiyle de ayrıcalıklıdır. TRT, uzun yıllar modernizmin ulus-devlet, kimlik ve toplum savları, TRT ve onun kültür yayın programlarının başat dayanakları olmuştur. Bu yayın misyonu, zamanla dönüşen postmodern dünyanın argümanları ile çelişmeye başlamıştır. Modern Türkiye'nin yaratılan türkü algısı, postmodernizmin bir gerekliliğine; posttürkü ye dönüşmüştür. Çalışma içerisinde, yarı kurgulu görüşme yöntemi ile görüşmeler yapılmış, doküman analiz yöntemiyle türkü tanımlamalarına ulaşılmış, TRT ve onun uygulamaları üzerinden eleştirel bir bakış açısı ile var olan türkü tanımlamaları sorgulanmıştır.
\end{abstract}

Anahtar Kelimeler: Kültür, türkü, halk müziği, kültürel dönüşüm, posttürkü.

\begin{abstract}
The music policies of the Republican period are in search of many such as nation-state, homogeneous culture, and standard language concepts. TRT has a privileged point in the implementation and continuity of these policies. In particular, its efforts about moving and transfering traditional Anatolian music culture are quite meaningful. On the other hand, however, his political mission has significantly changed the traditional musical map of Anatolia. For many years, ideas of modernism such as nation-state, identity and society have been main sources of TRT and its culture broadcasting programs. In time, this broadcasting mission began to conflict with the arguments of the postmodern world. The perception of folk song created in Modern Turkey has become posttürkü which is a necessity of postmodernism. In this study, interviews were conducted with the semi-planned interview method, reached the definitions of folk song by the method of document-analysis, presented definitions of folk song are called into question with the critical view on TRT and its practices.
\end{abstract}

Keywords: Culture, türkü, folk song, cultural transformation, posttürkü

\footnotetext{
Araştırma Makalesi - Geliş Tarihi/Received Date: 02.05.2020 Kabul Tarihi/Accepted Date: 21.05.2020

* Sorumlu Yazar/Corresponding Author: Dr. Öğr. Üyesi, Sakarya Üniversitesi Devlet Konservatuvarı, mahirmak62@gmail.com ORCID ID: 0000000259163096
}

Atıf/Citation:Mak, M. (2020) Bir Kültürün Dönüşümü : “ Posttürkü”. Eurasian Journal of Music and Dance, (16), 1-33. 


\section{Extended Abstract}

The music policies of the Republican period contains many subjects such as nation-state, homogeneous culture, and standard language concepts. TRT has a privileged point in the implementation and continuity of these policies. In particular, its efforts about moving and transfering traditional Anatolian music culture are quite meaningful. On the other hand, however, his political mission has significantly changed the traditional musical map of Anatolia. For many years, ideas of modernism such as nation-state, identity and society have been main sources of TRT and its culture broadcasting programs. In time, this broadcasting mission began to conflict with the arguments of the postmodern world. The perception of folk song created in Modern Turkey has become posttürkü which is a necessity of postmodernism. In this study, interviews were conducted with the semi-planned interview method, reached the definitions of folk song by the method of documant-analysis, presented definitions of folk song are called into question with the critical view on TRT and its practices.

It is accepted that the steps taken with the efforts to create and nationalize a national culture first began with compilation efforts. However, the echoes of the steps that started with the Renaissance of Europe and the French Revolution were initialized with Tanzimat in the Ottoman Empire. In the early $20^{\text {th }}$ century, as a result of the "return to the people" movement, which is a result of the approaches such as Turkism and nationalism that we heard in the beginning of the century, folkloric steps started to be taken. As Cem Behar stated, we can say that this orientation gained momentum with the thoughts of Gokalp, which formed the basis of the official music policies of our republic for the first fifty years.

In this study, the new "folk song/türkü" perception created by the cultural interaction and transformation caused by migration movements and radio-television broadcasts, which started in the 1950s, was mentioned. The 1950s are an important period in which a series of developments took place. From these years, the ongoing official music policies of states has started to change. These official breaks caused unannounced practices between music foundations of the government. In the 1990s, with the start of the multi-channel broadcasting process, traditional music cultures were to transform in different ways. All developments would remain between applications which bless tradition and applications which see all transformations as a requirement. With the compilation works carried out with precision by the conservatories and state institutions, TV-radio broadcasts, which transfer the compiled material in line with the current broadcasting policies, would diverge purposefully from each other. The materials of this new culture, which is blended with tradition, are the musical perception of the process that started from the mid-twentieth century. After 1950s, the cultural transformation that took place on the folk songs such as abandoning anonymity, adopting personal performing style, samples of folk poetry composed were accepted as türkü. Within the framework of this new perception; in the past, accepted examples such as "Aşık Veysel folk songs" and "Neşet Ertaş folk songs" have been replaced by a popular form of performance where folk poetrylooking lyrics have been composed and sung.

In this study, the question of "What is folk song?" was tried to be answered by looking at the samples of music culture in the new period through the widely accepted folk definitions. The place of folk song in tradition was handled. In this context, the issues such as the traditional references of folk songs, the profile of folk song producers, the anonymity of the folk songs, the traditional transmission styles of the folk songs, the importance of the local folk song lyrics and performing style of the traditional instruments were tried to be explained. During the study process, the literature related to the field of study was scanned by using the documentation method (document analysis) and the criticism of the subject was made over the written sources. In addition, in order to support the basic ideas of the study, interviews were made by using the semi-structured interview technique. 
Cumhuriyet dönemi, ulus-devlet politikalarının kurumsal ölçekte kabulüne ve yeni kimlik arayışlarının gözlemlendiği bir dizi kırılmalara ev sahipliği yapar. Bu kırılmalar zaman içerisinde Anadolu'nun geleneksel müzik kültürü haritasının değişmesine neden olmuştur. Geleneksel müzik kültürünün doğal olmayan yollarla dönüşümüne; hükümetlerin müzik politikaları, radyo ve televizyon yayın politikaları, çok kanallı hayata geçiş, 1950’li yıllarda başlayan batı pop müzik akımı (Çevik, 2012 s. 145), 1960-1970 ve 1990’lı yıllarda ortaya çıkan Rock, Anadolu Rock, Türkçe pop müzik akımları, kırsal alanlardan şehirlere doğru göç, köy enstitüleri, halkevleri ve müzik eğitim kurumlarının kurulması, askeri darbeler, siyasal hareketler, ekonomik daralmalar, kırsal alanlardan kentlere göçle gelen toplulukların oluşturdukları kültür ve dayanışma adı altında kurulan derneklerin faaliyetleri, gibi bir dizi gelişme neden olmuştur.

Milli kültür yaratma ve millileşme çabaları ile atılan adımların, ilk olarak derleme çalışmaları ile başladığı kabul edilir. Ancak öncesinde, Avrupa'nın Rönesans'1 ile başlayan, Fransız ihtilali ile taçlandırılan halka yönelme adımlarının yankıları Osmanlı'da Tanzimat ile bulmuştur. Daha sonraları, 20. yüzyılın başlarında seslerini duyduğumuz Türkçülük ve milliyetçilik gibi yaklaşımların bir sonucu olan "halka dönüş" hareketinin bir sonucu olarak, folklorik adımlar atılmaya başlanmıştır (Elçin, 1997, s. 1-2). Cem Behar'ın da ifade ettiği gibi (2008, s. 271), cumhuriyetimizin ilk elli ylllık resmi müzik politikalarının temelini oluşturan Gökalp'in düşünceleri ile bu yönelim bir ivme kazanmıştır diyebiliriz.

Ardından konservatuvarların eğitim-öğretim hayatına geçmesi, Köy Enstitülerinin kurulması, Halkevlerinin açılması, TRT'nin (Türkiye Radyo ve Televizyon Kurumu) yayın hayatına başlaması ile birlikte, resmi olarak yeni kültür inşasının temelleri atılmışıır' ${ }^{1}$. Geçmişe dönük uygulamaların politik karşılıklarını, günümüz müzik eğitimöğretimi içinde, yayıncıllğında ve diğer kurumlar nezdinde gözlemleyebilmek hala mümkündür. Gelenekten beslenen, onu korumayı şiar edinmiş ve kimi zaman gelenekselliği kutsayan yaklaşımlar, zaman içinde kültürel bir dönüşüme de sebebiyet vermiştir. Görünen uygulamalarının geleneğe atfeden modern yüzü, kendi kültürel argümanlarını oluşturmuştur. Gelenek ile bağlarını koparmayan, ancak yeni dünyanın müzik anlayışı ile örülü icra biçimi geliştiren örnekleri oldukça fazladır. "Çağın Aş̧k Veysel'i" Cengiz Özkan konunun betimleyici örneklerinden biridir. Öyle ki, oldukça yakın bir geçmişin halk ozanı Aşık Veysel'in sesinden dinlemektense, Cengiz Özkan'dan dinlemeyi tercih eden yeni dinleyici profili de, tam olarak sözünü ettiğim oluşturulmuş türkü algisinin sonucudur.

Gelenek, geçmiş ile ilişkilendirilen bir sözcüktür. Bilhassa modern toplumlarda modernin karşıtı olarak görülmüştür. Ancak, geleneğin üzerine yapılan tartışmalara bakıldığında, net bir tanımı üzerinde fikir birliğine varılamadığını görürüz. Bu çalışmada gelenek, Sibel Özbudun'un Seymour-Smith'in gelenek tanımlaması üzerinden yaptığı değerlendirmesi ele alınacaktır. Bu tanıma göre gelenek; toplumsallaşma yoluyla bir kuşaktan diğerine aktarılan inanç, adet, davranış, bilgi ya da uzmanlık öğretilerinin bütünüdür (aktaran Duran, 2014, s. 3839). Ancak her zaman geleneğin tarihsel bir uzantısı olduğu fikri yanılgıdır. Gelenek; modern toplumların ideolojik olarak yaratmaya çalıştığı, tarihsel bir arka planla ilişkilendirilmiş, toplumsal birlik, aidiyet, bütünlük sağlamak veya statü ve otorite ilişkilerini meşrulaştırmak için oluşturulmuş kurallar, davranışlar ve semboller bütünü olarak

\footnotetext{
${ }^{1}$ Yeni dönem türkü anlayışının oluşmasında TRT’nin varlığı üç açıdan önemlidir. Bunlardan ilki, bir devlet kurumu olması, dolayısıyla hükümetlerin izlediği kültür politikalarının görünür kılması noktasında değerlidir. İkincisi, ise, kurumsal ölçekte bir iddia ile kültür taşıyıcısı misyonu üstlenmesi ve bu anlamda yaptığı faaliyetleridir. Kuruluşundan bugüne, yaptığı derleme çalıșmaları, bünyesinde yer verdiği türkü yayınları, ses ve saz sanatçısı kadrolarıyla özel bir kurumdur. Üçüncüsü ise, 2000'li yıllara gelindiğinde “TRT Türkü” adıyla yalnızca türkü yayını yapan bir radyo kurulmasidır.
} 
da karşımıza çıkar. Bu karşılaşma içinde, geleneğin olağan var oluşunu aramamak gerekir. Çünkü bu yapay süreç sonunda gelenek, icat edilir.

Bu çalışma içerisinde, 1950'li yıllara girerken başlayan, göç hareketlerinin ve radyo-televizyon yayınlarının neden olduğu kültürel etkileşim ve dönüşümün yarattığı yeni “türkü” algısına değinilmiştir². 1950’li yıllar bir dizi gelişmenin yaşandığı, önemli bir dönemdir. Çevik (2012, s. 131) bu yıllardan itibaren, devletin süre gelen resmi müzik politikalarından kopmaya başladığını ifade eder. Resmi olarak görülen bu kopuşlar, kurumsal bazda birbirinden habersiz uygulamalara neden olmuştur. 1990’lı yıllara gelindiğinde, çok kanallı yayın sürecinin başlaması, geleneksel müzik kültürlerini farklı bir yöne doğru dönüştürecektir. Yaşanan tüm gelişmeler, geleneği kutsayan uygulamalarla, tüm dönüşümleri bir gereksinim olarak gören uygulamalar arasında sıkışacaktır. Konservatuvarlar ve devlet kurumları bazında yapılan ve hassasiyetle yürütülen derleme çalışmaları ile derlenen malzemeyi mevcut yayın politikaları doğrultusunda aktaran televizyon ve radyo yayınları, birbirinden amaçsal olarak ayrışacaktır. Gelenekle harmanlanmış dönüşen bu yeni kültürün malzemeleri, yirminci yüzyılın ortalarından itibaren başlayan sürecin müzik algısıdır. Şenel (2011, s. 73), 1950’lerden sonra yaşanan kültürel dönüşümü türküler üzerinden değerlendirirken; halkın nezdinde geleneksel paylaşım ve etkileşim sürecini deneyimlememiş kişiye özgü icra tarzlarının ortaya çıktığını, halk şiiri tarzındaki şiirlerin ise bestelenerek türkü diye anıldığından söz eder. Şenel, bu yeni algı çerçevesinde ortaya çıkan; geçmişte “Aşık Veysel türküleri” ve "Neşet Ertaş türküleri” gibi ifade edilen, kabul görmüş örneklerin yerini, halk şiiri görünümlü güftelerin bestelenip söylendiği popüler bir icra biçiminin aldığını ifade etmektedir.

Bu çalışmanın çerçevesini belirlediği alan içerisinde, TRT'nin öncülüğünü yaptığı halk müziği dönüşümünün sonuçları üzerinden türkü tanımlaması yapılmıştır. Zira TRT, Cumhuriyet'in kuruluş ilkelerine paralel güdülen politikaların görünür olması münasebetiyle özel bir yerde durur. TRT kurumunun, bu politikalara paralel doğrultuda yalnızca dinleyenleri eğiten bir misyonu yoktur. Aynı zamanda bünyesindeki ses ve saz sanatçılarını da yetiştirmiş̧tir. Aksoy’un (2008, s. 182-183) bir eğitim kurumu olarak gördüğü radyonun, cumhuriyetin kültür programının bir bütün olarak halka yayılmasında çok etkili bir kurum olduğu yönündeki tespiti bu açıdan anlamlıdır. Aksoy (2008, s. 197), bir okul gibi eğitim veren radyonun zamanla musiki icrasında yerleşik gelenekleri değiştirdiğini de söyler. Bu değişimin bir sonucu olarak, "Değişen, dönüşen yeni müzik kültürü ürünleri ne ölçüde türkü kabul edilmeli?” sorusuna cevap bulmadan evvel; yapılmış türkü tanımlamaları ve tartışmalarına bakılmıştır. Yeni dünya düzeni içerisinde Anadolu İnsanı tanımlaması değişmiş, doğal olarak eskisinden farklı yeni kültürel alanlar ortaya çıkmıştır. Görünen bu tablo içerisinde ise türküyü yeniden tanımlamak haiz olmuştur. Bu ihtiyaçtan hareketle, geçmişte Anadolu insanının -dolayısıyla Anadolu kültürünün- türkü üretim sürecinin akademi nazarında nasıl tanımlandığı gösterilmeye çalışılmış; sosyal, politik, ekonomik ve kültürel değişkenlere bağlı yapılan tanımlamalar, sözünü ettiğim bu referans kavramların değişmesiyle yeniden yapılmıştır.

\section{Araștırma Problemi}

Çalışma içerisinde, kabul görmüş türkü tanımlamaları üzerinden, yeni dönem müzik kültürü örneklerine bakılarak “Türkü nedir?” sorusuna yanıt aranmaktadır. “Gelenekte türkü nedir?” sorusuna etraflıca cevaplar

\footnotetext{
${ }^{2}$ Resmi olarak izlenen müzik politikalarının, 1940’lı yıllardan itibaren değişime başladığı görülür. Demokrat Parti iktidarı ile izlenen müzik politikaları kesintiye uğrar ve 1950 yıllarından sonra süregelen müzik politikalarından uzaklaştı̆̆ı görülür (Aktaran Çevik, 2012: 128).
} 
aranmıştır. Bu bağlamda, geleneğe atfedilen türkü tanımlarında sıkça vurgulanan, türkülerin geleneksel üretim mekanları, türkü üreticilerinin profili, türkülerin anonimliği, türkülerin geleneksel aktarım biçimleri, türkü sözlerinin yerelliği, yöreden yöreye göre değişen geleneksel çalgı ve çalgısal özellikler, türkülerdeki tema ve meşk gibi temel referansların ne şekilde ve nasıl değiştiği anlatılmaya çalışılmıştır. Bu değişimlere bağlı olarak, çoğunlukla gelenekten beslenen, gelenekten farklı olarak yeni mekanlarında yapanı belli, belli bir topluluk tarafından kabul görmüş, iç dinamizmi-organizasyonları ve kuralları olan, belirli bir ağız-şive ve lehçe özelliği taşıyan, yeni bir müzik kültürü ortaya çıkmıştır.

\section{Amac}

Dönüşen, değişen ekonomik ve sosyo-kültürel yapının, müzik kültürü üzerindeki etkileri kaçınılmazdır. Bu gerçekle, araştırmacılar nezdinde geniş kabul gören var olan türkü tanımının, yeniden yapılması elzemdir. 20. yüzyıl ortalarından günümüze değin varlığını sürdürmüş TRT yayınları ile günümüz Türkiye'sinin yeni müzik kültürü örnekleri arasında organik bir ilişki bulunmaktadır. Bu perspektiften yola çıkarak; kutsanmış geleneksel icra ile yerilen günümüz müzik kültürü örnekleri arasındaki ilişkinin, türkü tanımı üzerinden yeniden değerlendirilmesi amaçlanmıştır.

\section{Yöntem}

Çalışma sürecinde dokümantasyon metodu (doküman analizi) kullanılarak, çalışma alanı ile ilgili literatür taranmış ve yazılı kaynaklar üzerinden konunun kritiği yapılmıştır. Yanı sıra, çalışmanın temel fikirlerini destekleyebilmek için iletişime geçilen kişi veya kişilerle de, yarı kurgulu görüşme tekniği kullanılarak görüşmeler yapılmıştır.

\section{Türkü Nedir?}

Genel olarak türkü, sözcük anlamı itibariyle hem bir nazım biçimine, hem de bir ezgi kalıbına gönderme yapar. Ancak her iki durumda da standart bir kalıptan ve yapıdan söz etmek mümkün değildir. Esasında bu değişkenlik, türkünün en belirgin özelliği olarak karşımıza çıkar. Tematik olarak incelendiğinde, türkülerde işlenmiş konularda da farklılıklar görürüz. Ağıt, aşk, afetler, savaşlar, göç, kahramanlık vs. gibi bir halkın ya da insanın yaşayabileceği olaylar işlenmiştir. Ancak bu tasniflerde bile, bir türkü içerisinde homojen bir konu bütünlüğünün oluşmadığ 1 durumlar da vardır . Yanı sıra, işlenen konu ve hece vezninin ayrıştırdığı bu tabloda, edebi olarak da standart bir yapıdan söz etmek mümkün değildir. Söz gelimi bir varsağının türkü olabileceği gibi, koşma da, ninni de bir türkü olabilir.

Türkü icra etmek anlamına gelen ve bir performans halini niteleyen sözcük ve fiiller de çeşitlidir. Anadolu'da kullanılan Türkçe'nin dil yapısına göre değişkenlik gösteren bu ifade biçimleri; türkü dizmek, türkü yırlatmak, türkü çı̆̆ırtmak, türkü çı̆̆ırmak, türkü çağırmak, türkü söylemek, türkü tutturmak, türkü yakmak, asılmak, türkü havalandırmak, çekmek, ayıtma (Özbek, 1998, s. 19), düzme, ylr, şarkl, deme, deyiş, yır, hava/türkü ayltmakçölmek-çığırmak-okumak (Gazimihal, 2006, s. 216), şarkı-deme-deyiş-hava-gayda (Boratav, 1978 s. 150) gibi sözcük ve fiilerin kullanımı ile çeşitlilik gösterir.

\footnotetext{
${ }^{3}$ Söz gelimi TRT Repertuvarında bulunan, repertuvar numarası 9 olan Endim Dere Beklerim türküsünde aşk ve ayrıllk konuları birlikte işlenmiștir.
} 


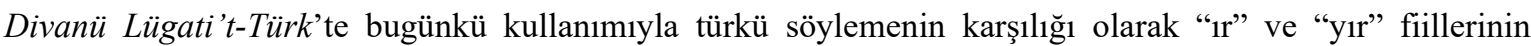
kullanıldığını görmekteyiz (Atalay, 1992 s. 3; Arat, 1986, s. 15). Benzer ifade biçimleri bugün bile Türk coğrafyalarında hala kullanılmaktadır. Özellikle Elazı̆̆ ve Muş dolaylarında 'yır' ve 'ır' sözcükleri hâlâ kullanılır (Daloğlu, 2017, s. 147). Ancak zaman içinde, Yazıcı'nın da belirttiği üzere (1995, s.1), Türklerin yaşadığı coğrafyanın şekillenmesi ve bu coğrafyanın İslam dini ile tanışması, dolayısıyla farklı kültürlerle etkileşim halinde kalmasının doğal bir sonucu olarak; Türk coğrafyasını ve kültürünü niteleyen 'Türke ait' anlamına gelen 'türki/ü' sözcüğü ortaya çıkmıştır. Ancak sözcüğün tüm Türk coğrafyasını tanımlamak için kullanıldığı fikri doğru değildir. Geleneksel sözlü-sözsüz halk ezgilerine Kırgızlar 'türkü', Başkurtistan’da 'halk yırı', Tataristan'da 'halk cırı', Türkmenistan'da 'halk aydımı', Kazakistan'da 'türük', Özbeklerde ‘türki' 'halk koşiği', Tatarlarda 'halık cırı', Uygurlarda 'nahşa', Irak Türklerinde 'beste' 'mahnı' 'halk türküsü', Gagauz Türklerinde 'türkü' demektedir (Sakaoğlu-Alptekin, 2006, s. 593; Pelikoğu, 2012, s. 22).

Yakıc1 (2013, s. 38), türkü sözcügünün ilk olarak 15.yy’da yazılmış bir metinde geçtiğini ifade etmektedir. Bu yüzyılda yaşayan Türk Edebiyatı'nın önemli temsilcilerinden Ali Şir Nevai'nin Mizânu'l-Evzan isimli eserinde, bir şarkı türü olarak ifade edilmektedir. Ancak Gazimihal (1961, s. 258), sözcüğün ilk kullanılan kaynağına ilişkin 14. yüzyılda yazılmış Kabusname eserinin tercümesine işaret eder. Sözcüğün Anadolu' daki varlığına dair ilk yazılı metin ise 16. yüzyıl halk şairi Öksüz Dede’ye ait bir şiir kabul edilir (Dizdaroğlu, 1968, s. 259). Öksüz Dede’ye ait bu şiir, sekizlik hece kalıbı ile yazılmış iki dizeli kavuştaklardan oluşmuştur.

Çobanoğlu (2010, s. 47) bu görüşten farklı olarak sözcüğün “Türk Küyi/Küyü” Türk ezgisi anlamındaki tamlamasının zamanla “Türkiy” e dönüştüğünü söyler. Küy ya da zaman zaman küğ olarak da karşımıza çıkan sözcük, şark1/ezgi anlamında kullanılır (Duygulu, 2014, s. 311; Eroğlu, 2017, s. 82). Ancak bu sözcük, Asya'da yaşayan Türklerin müzik terminolojisi içinde kullanılır. Sonuç itibariyle, sözcüğün etimolojisi üzerine neredeyse fikir birliğine varılmış gibidir. "Türki” ifadesinden türediği, Arapçada yer alan nispet [i] harfi sona eklenerek (aktaran Yakıcı, 2013, s. 34) Türk’e ait, Türk’e özgü anlamı kazanmıştır (Eroğlu, 2017, s. 80; Birdoğan, 1998, s. 23).

Türküler yapısal olarak genellikle hece vezni ile yazılırlar. Bilhassa divan, hoyrat icralarının yaygın olduğu Urfa, Diyarbakır, Kerkük, Harput, Mardin gibi merkezlerde rastladığımız aruz vezni ile de yazılmış örnekleri de bulunmaktadır. Aruz vezni ile yazılan bu örnekler divan edebiyatında her ne kadar farklı isimlerle (Divan, selis, semai, kalenderi, satranç ve vezniahr) anılsalar da, geleneksel halk müziği içinde türkü adı ile bilinmektedir. Daha ziyade geleneksel halk müziği içinde aruz kalıbıyla yazılmış, serbest bir ritim ${ }^{4}$ ile icra edilen (bazen belirli bir ritim kalıbı üzerine tekrar eden ezgiler üzerine de okunulur) bu tür yapılar 'uzun hava' olarak adlandırılırlar (Pelikoğu, 2012, s. 23). Örneğin, Elazı̆̆ yöresinden derlenmiş, sözleri Hacı Hayri Bey’in, aruz vezni ile yazılmış Sinemde Bir Tutuşmuş Yanmış Ocağ Olaydı eseri bir türküdür (Eroğlu, 2017, s. 86). Kısaca sözlü halk ezgileri için tür, biçim, form yapıları gözetmeksizin türkü olarak kabul görülür.

Püsküllüoğlu ise türküyü "sözleri genellikle hak şiiri biçiminde olan, yazanı ve besteleyeni bilinmeyen, halk ezgileriyle oluşturulmuş bir şarkı türüdür. Halk şiirinde hece ölçüsü ile yazılan, genellikle kavuştaklı, bireyin ya da toplumun acılarını, sevinçlerini dile getiren kendine özgü bir ezgiyle söylenen bir koşuk biçimi türüdür(1995,

\footnotetext{
${ }^{4}$ Süleyman Şenel, "uzun hava” yerine "serbest ritimli ezgiler” demeyi daha uygun görmektedir. Ayrıntılı bilgi için bknz. Şenel, S. (2000), Türk Halk Müziğinde "Uzun Hava" Tanımları ve Bu Tanımlar Etrafında Ortaya Çıkan Problemler, Türk Halk Müziğinde Çeşitli Görüşler içinde, s. 55-81, Ankara: Kültür Bakanlığı Yayınları.
} 
s. 1532-1533)" diye ifade eder. Seyit Kemal Karaalioğlu'nun hazırladığı Ansiklopedik Edebiyat Sözlüğü, Sami Akalın'ın Edebiyat Terimleri Sözlüğü, Emin Özdemir'in Edebiyat Bilgileri Sözlüğü’nde de benzer türkü tanımlarına rastlanmaktadır (Yakıc1, 2013, s. 34). Fuad Köprülü (1993, s. 246) ve A. Talat Onay (1996, s. 63) ise türkü tanımını daha ziyade kullanılan ezgi kalıpları üzerinden yapar.

Türk Dil Kurumunun (TDK) hazırladığı güncel Türkçe sözlügü içinde yer alan türkü maddesi (2019), "hece ölçüleriyle yazılmış halk ezgileriyle bestelenmiş manzume" olarak geçer (Türk Dil Kurumu, erişim adresi: https://sozluk.gov.tr). İslam ansiklopedisinde ise türkü maddesi:

Türkü; genellikle Osmanl1-Türk sözlü halk ezgilerini tanımlamak için, Türk sanat müziğinin şarkı formunun karşlığı olarak, basit melodilerle örülü, işlenen konular bakımından geniş bir alana yayılmış folksong (sözlü halk ezgisi) türüdür.

1. Folksongların çoğunun sözleri anonimdir. Kalanı ise halk şiirlerinden oluşmuştur (sözleri yazanı belli/mahlası verilmiştir).

a. Türkü türünün ana yapısını hece vezni oluşturur.

b. Aruz vezni de kullanılır. Divan, gazel, murabba örneklerinde olduğu gibi.

2. Türkülerin bir diğer yapısal özelliği, sine denilen melodi/ezgi bölümüdür. Belirli karakteri olan anonim ezgilerdir bunlar.

a. Bu melodiler, parlando yani usulsüz ezgilerdir (Uzun hava).

b. Bu melodiler ise usullü ezgilerdir.

3. Türkü, din hariç diğer tüm ilgi alanlarının tamamını kapsar.

4. Türkünün dili ise genellikle popüler Türkçedir ve önemli ölçüde Arapça ve Farsçadan taşınmış sözcüklerden bağımsızdır (Ambros, 2019).

Özbek (1981, s. 63) ise türküyü, geçmişten gelen, zamanla biçimlenmiş, ait olduğu topluluk tarafindan heyecanla çalıp söylenmiş, toplumun kendisini içinde bulduğu ezgili-sözlü edebi ürünler olarak ifade eder (Büyükturan, 2019, s. 14). Büyükturan'ın Özbek ile yaptığı mülakatta “Derlemeye konu olacak nasıl türkülerdir?” Sorusuna Öbek; türkülerin halk işi olması ve ezgi yapısının yerel ve otantik karakterli olması gerekliliğinden söz eder. Halk işi ifadesini ise sözün halk şiiri özelliği taşıması anlamında kullanır. Özbek halk işi ezgi ve söz kalıplarının kullanılarak yapanı belli türkülere "bireysel türkü" adını verir. Zamanla bu türküler bireysel özelliklerini kaybederek ortak bir hal aldığını ifade eder (Büyükturan, 2019, s. 14-16). Özbek'in türkü tanımları içinde "ezgili-sözlü edebi olması", "halk işi olması”, “otantik karakterli olması” ve "bireysel türkü” tanımlamaları öne çıkar. "Bireysel türkü" tanımlamasını, yapanı belli olan üretimlerinin getirdiği kavram kargaşasından ayrıştırmak için kullanır.

Atılgan ise, sosyal hayatın doğal bir sonucu olarak beliren, anonimleşme sürecini tamamlamamış, ancak bu özelliği dışında tamamıyla türkü olarak kabul gören yeni üretimlere dikkat çeker. Atılgan bu ayrımı, anonim 
türküler ve beste türküler olmak üzere iki başlık altında yapar (Büyükturan, 2019, s. 23). Atılgan, Alevi inanç ve ritüellerinde kullandıkları sözlü ezgili örnekleri ise türkü olarak nitelemez. Onun için nasıl bir ilahi türkü olarak tanımlanmıyorsa, Alevi müzik kültürü örnekleri de tanımlanmamalıdır (kişisel iletişim, 01.05. 2020).

Karadeniz (2010, s. 54) ise türküyü geleneksel ve geleneksel olmayan olarak ayrıştırır. Karadeniz, yapıcısı belli olmayan halk ezgilerine türkü derken, anonim bir halk şiirinin bestelenmesi ya da geleneksel bir ezgiye söz yazılması, onu geleneksel olmaktan çıkarır der. Hatta bu maksatla bugün TRT repertuarında bulunan bazı şahıs eserlerinin, anonimmiş̧ gibi kayıt altın alındığını söyleyen Karadeniz (2010, s. 57), Ali Ekber Çiçek’ten alınma Haydar Haydar ve Erzincan yöresi Aşık Daimi'den alınma Yarim Senden Ayrllalı türkülerini örnek verir. Türkü tanımını ise şöyle yapar:

1. Türkünün sahipsiz olması

2. Gelenekselleşmiş ve yaşamda bir ortaklaşalığa dönmüş olması

3. Toplumun benimseyip kendi dili ve ifade biçimiyle örtüşmesi

4. Genelde söze dayalı olarak yayılması

5. En azından belli bir bölgede yaygınlığı

6. Folklorik açıdan yöresel özellikleri barındırması

7. Zamana yayılmış belli bir geçmişi olması.

Hoşsu ise Tüfekçi (1995, s. 1482) gibi, halk sanatı diye ayrımını yaptığı geleneksel halk müziği örneklerinden türküyü (Türk halk müziğini) şöyle tanımlamaktadır;

1. Sahibi bilinmeyen

2. Halk tarafindan benimsenip onun ifadesine bürünmüş olması

3. Kulaktan kulağa aktarılması

4. Gelenek haline gelmesi

5. Zaman içerisinde derin bir geçmişinin olması

6. Halkın ortak malı olması (anonim)

7. Mekân içinde yaygın olması

8. Yöresel dil ve müzik özelliklerini taşıması

9. İddiasız olması (sanat kaygısı taşımaması)

10. Kişisel yapım olmaması (anonim) (1997, s. 7). 
Dirican'ın Erol Parlak ile yaptığı mülakatta (2019, s. 18-19) Parlak; türkülerde aranılan anonim olma özelliğine eleştirel bakmaktadır. Parlak, türkünün var olma sürecinin bireysel bir yaratım ile başladığı, ancak zaman içinde teknolojik kayıt imkanlarının yetersizliği başta olmak üzere, ilk yaratıcısının kaybolarak anonimleştiğini ifade etmektedir. Ancak günümüzde kayıt teknolojisinin gelişmesi ile eserin ilk yaratıcısının kaybolmasının mümkün olmadığının da altını çizer.

İcracının içinden geldiği müzik kültürüne, icracının müzik yeteneğine, kabiliyetine ve beslendiği müzik kültürüne bağlı olarak, gelenekte olduğu gibi kulaktan kulağa aktarılan türkülerde icracıdan icracıya göre farklı performanslar görülebilir. Büyükturan'ın (2019, s. 16) Yücel Paşmakçı ile yaptığı görüşmede Paşmakçı, derleme çalışmalarının önemini anlatırken bu hususta; halk müziğinin geçmişten günümüze değin kayıplar vererek geldiğini, hatta aynı evde yaşayan iki kişinin aynı türküyü farklı şekillerde söylediğini tespit ettiğini dile getirir.

Öztuna (1976, s. 347) ise türküyü nazari açıdan değerlendirerek, Türk sanat müziğindeki şarkı formunun bir karşılığı olarak görür. Geniş bir tanımlama yaparak türküleri bir halk sanatı olarak tanımlar (Öztuna, 2006, s. 327).

Eroğlu ise türküyü, tarihi derinliği içerisinde inceleyerek, onu gelenekselliği üzerinden anlatır. Gelenekselliği tarihi bir süreç olarak gören Eroğlu, Türk halk müziğini ise şöyle tanımlar: "üreteni, yapanı unutulmuş ya da eserin tanınırlıkla sahibinin önüne geçtiği, geleneğe dayalı ve geleneksel usullere göre üretilmiş olan bu müziğin orijinini, yani kültürel kökleri-kaynakları; üretim ve icra ortamları, usta mahalli söz ve saz sanatkarları, yani halk şairleri ve aşıklar, doğal olarak da bu müziğin, kanaatimizce tek çıktısı olan “türkü” akla gelmektedir (2017, s. 80)" şeklinde ifade eder. Gazimihal de türküyü, kulaktan kulağa aktarılmış ve halk aşıkları vasıtasıyla yayılmış olmaları temelinde değerlendirir (2006, s. 3).

Altınay, halk müziğini kültür ve üretim ilişkileri üzerinden tanımlamayı uygun görür. Altınay yaptığı tanımda; “Halk müziği, uygarlık ve kültür açısından yüksek düzeye ulaşmış toplumların, kırsal bölgelerde ve yörelerde, köy, oba gibi yerleşim yerlerinde yaşayan toplumsal katmanlarında gelişmiş olan müziklerdir (aktaran Burç, 2009, s. 5)" der.

Türkülerin şiir yapısını biçimsel olarak ele alan, halk edebiyatı nazım biçimi olarak tanımlayan görüşler de bulunmaktadır. Bu görüşler genel olarak, türkülerin sözlerinin biçimsel olarak kullanımı/dizilimini ya da genel anlamıyla halk şiiri çeşitliliğini göz ardı ederek ezgi ile ilişkilendirip bir bütün olarak değerlendirir. Bu bağlamda Elçi de türküyü biçimsel olarak ele alır. Ona göre türkü; sözlü halk ezgilerinin en çok rastlanan biçimi olan “bentlerden” sonra "bağlantı” denen, tekrar edilen kısımların eklenmesi ile oluşan ezgili yapıdır (Elçi, 1997, s. 83). Pertev Nail Boratav (1982, s. 50), Cem Dilçin (2000, s. 289) ve Başgöz (2008, s. 15) de daha genel bir tanımlama yaparak türküleri ezgili söylenen şiirlerin genel adı olarak görür.

Yakıcı (2013, s. 51), türkülerin oluşumunu üç evreye ayırır; "kaynaktan çıkar, dolaşır ve değişir” der. Bu üç evre sonunda türkülerin, anonimleşip, yaygınlaşıp, üretildiği ilk halinden bağımsız (kimi zaman her icra da yeniden üretildiği), değişim gösterdiği düşünülmelidir. Ancak her zaman türkülerin ilk üreticisinin izleri kaybolmaz. Türkülerin anonim olma özelliği bu durumlarda aranmaz. Bu sebeple Yakıcı, türkülerin kaynağını bireysel ve anonim türküler olmak üzere ikiye ayırır. Özbek de, halk türküsü ve şahsın türküsü şeklinde ayrıştırır ve bireysel özelliklerini kaybeden bu oluşumlara 'halk türküsü', bireyselliğini koruyanlara ise 'türkü', 'Ahmet'in türküsü', 'Neşet Ertaş türküsü’ denmektedir(2009, s. 19; 2019, s. 15)" şeklinde dile getirir. Benzer biçimde Sakoğlu ve Alptekin de (2006, s. 593) türkülerin belirleyici ayrımını anonimlik ve bireysellik üzerinden yapar. 
Genel yaklaşım sözsüz geleneksel halk ezgilerini (oyun havaları, halaylar, taksimler vs.) ve uzun havaları türkü tanımının dışında $\operatorname{tutar}^{5}$ (Eroğlu, 2017, s. 83-84). Yapılan tanımlara bakıldığında, türkünün halk şiiri özelliği taşıyan şiirlerinin ezgili icralarına denildiği söylenebilir. Özbek de (2010, s. 20) benzer biçimde, türkülerin halk şiirlerinin (koşma, türkü, mani, divan, gazel gibi) kırık hava biçiminde okunmuş sözlü ezgilere denildiğini ifade eder. Genel yaklaşımın Özbek'in ifade ettiği gibi türkülerin ezgili halk şiirlerinin genel adı olduğu yönündedir (Duygulu, 2014, s. 218-219; Başgöz, 2008, s. 15). Ancak tam anlamıyla tartışmasız bir tanımın etrafında buluşulduğu söylenemez. Türküyü net olarak tanımlamanın yanılgısından söz eden Dizdaroğlu (1969, s. 102-103), genel bir ifadeyle ezgiyle söylenen her manzum parçaya türkü demeyi uygun görür.

Çevik (2012, s. 29), yapılmış türkü tanımlarının dört noktada buluştuğunu söyler. Bu özellikleri “Türklere mahsus olmaları, manzum bir metne sahip olmaları, belirli bir ezgi ile söylenmeleri, metin-ezgi ve çalgısıyla geleneksel bir nitelik göstermeleri” olarak sıralar. Esasında var olan türkü tanımlamalarına bakıldığında, yeni Türkiye'nin türkü algısı; ezgi yapılarının geleneksel, yerel unsurlar taşıması ilk sırada gelir ${ }^{6}$. Israrla anlatılmaya çalışılan şey, Bir halk şiirini, piyano ile çalıp, batı müziği şan tekniği ile söylediğinizde onun türkü olmayacağıdır. Ancak geleneğe dayalı yerel ezgi yapıları ile icrası, onu türkü tartışmasının içine sokar. Bunu fark eden müzisyenler, oluşan toplumsal ihtiyaca istinaden anonim halk şiirlerini ya da halk şiirine uygun manzum yapılar kullanıp onlara geleneksel ezgi kalıpları giydirmişlerdir. İşte bu çıkmaz karşısında, ortaya çıkan uygulamaların yakın geçmiş örnekleri için “türkü” veya “Ahmetin/Mehmetin türküsü” tanımlamaları getirilmiş; çok daha yeni örnekleri için ise "türkü formunda beste” yakıştırması yapmışlardır. Ancak dönüşüm, yalnızca süregelen türkülerin yeni üretim biçimlerinde yaşanmamıştır. Müziğin olağan kolektif üretim sürecinin tümünde; çalgılarında, üretim mekanlarında, konularında, dinleyen ve icracı profilinde, icra biçimlerinde, aktarım biçimlerinde yaşanmıştır.

\section{Türkülerin Üretim Mekanları}

Geleneğin müziğinin üretim mecraları ile bugünün müziğinin üretim mekanları arasında farklılıklar vardır. Yeni ve eski müziğin üretim alanları, fiziki görünümden bağımsız, içerik ve yapısal olarak ayrışır. Dönüşen müzik sektörü, küreselleşme, kurumsal olarak karşımıza çıkan yapılar (konservatuvarlar, halkevleri, köy enstitüleri, radyolar, televizyonlar, özel müzik kursları gibi), 1950’li yıllarda başlayan göç ve buna bağlı kültürler arası etkileşim, bugünün müziğinin üretim mekanlarının oluşumuna zemin hazırlamışlardır. Türkiye özelinde karşılaştığımız, kültürler arası etkileşime ön ayak olan gelişmelerin arasında, 1950'li yıllardan itibaren başlayan kırsal alanlardan şehir merkezlerine veya büyük şehirlere yaşanan göç olmuştur ${ }^{7}$. Bu gelişmelerin doğal bir sonucu olarak, geleneksel sözlü/sözsüz halk ezgilerinin ana üretim mecraları da değişmiştir. En anlamlı örnekleri, ülkenin batısına doğru yaşanan göçle gelen Anadolu insanın taşıdığı ve yeni dünyanın kuralları ile şekillendirdiği türkübarlardır. Terzioğlu (2007, s. 62), bu yerleri kenti ve kırsalı bir arada yaşatan, bu iki kültürün kesiştikleri temel

\footnotetext{
${ }^{5}$ Süleyman Şenel'in 'Türk Halk Musikisinde Uzun Hava Tanımları ve Bu Tanımlar Etrafinda Ortaya Çıkan Problemler' başlıklı makalesinde, halk müziği tasnifini benzer biçimde yapan ilgili görüşlere ayrıntılı bir biçimde yer verilmiştir.

${ }^{6} \mathrm{Bu}$ tespite örnek teşkil etmesi münasebetiyle, İsmail Altunsaray’ın seslendirdiği TRT Repertuvarında 2053 repertuvar numarası ile kayıtlı Ağasarın Balını isimli türkü, Altunsaray’ın yorumu ile tipik bir İç Anadolu türküsüne dönüşür. Müziğin yerel dinamiklerinin, çalgının ve icra tarzının değişmesi ile bir türkünün ne ölçüde yeni bir kimlik kazandığının en güzel örneklerinden biridir. (Erişim adresi: https://www.youtube.com/watch?v=FQsIv5TY6zE)

${ }^{7}$ Konuyla ilgili olarak kapsamlı bir araştırma olan, Yeni Ankara müziğinin oluşumunu anlatan Ömer Can Satır'ın hazırladığı Yeni Ankaralı Müzik Anlayışı ve Eğlence Pratiklerinin Dönüşümü başlıklı doktora tezi incelenebilir.
} 
mekanlar olarak görür. Türkü-barlar, müzikholler, gazinolar, çay bahçeleri, pavyonlar (Ankara yeni eğlence mekanları) sosyal bir gereksinimin sonucudur. Canbaz da (2015, s. 52) benzer biçimde, diğer eğlence mekanlarının yanı sıra bu tarzdan mekanlarda yapılan müziğin, bir kesim topluluğun müzik ihtiyaçlarına cevap vermek amacıyla oluştuğunu ifade eder.

Geleneğin içinde yer alan düğünler, cenazeler, olaylar, kısaca geçmiş topluluklar arası etkileşim noktaları yeni dünya içerisinde dönüşmüş ya da kaybolmaya yüz tutmuştur. Göç, yeni dünyanın halk müziklerini ürettikleri mekan farklılıkları ve bu mekanlardaki müziğin üretim kuralları, kitle iletişim araçlarının yaygınlığı ve bu araçların güdümündeki müzik politikaları, yeni türkü algısının temellerini oluşturmuştur.

Türkülerin yayılıp, taşınıp ve aktarılmasında, diğer bir bakış açısıyla kültürler arası etkileşimde Anadolu aşık ve ozanları büyük rol oynamıştır. Emnalar, halk aşıklarının sırtlarında sazları, bir yerde yaşanan olayı (aşk, savaş, afet, ölüm vs.) işleyerek; kimi zaman duydukları, el aldıkları, çoğu zaman kendilerinin can verdiği halk ezgilerini, yöreden yöreye taşımış olduklarından söz eder (1998, s. 55). Önceleri geleneğin içinde görebildiğimiz bu işleyiş, toplumun bilgi alma ihtiyacı, ibadet geleneği, müzik ihtiyacı ve halk aşıklarının ekonomik gereksinimlerine istinaden gelişmiştir. Geçmişte halk aşıkları için düğün yerleri, özel müzikli toplantılar, kahvehaneler, aşık buluşmaları müziğin üretildiği ana mekanlar olmuşlardır. Üretim biçimlerinin şekillendirdiği müzik kültürü örneklerine bakıldığında, müziğin üretildiği mekanların çeşitliliği, her bir topluluk için farklı alanlara işaret eder. Toprağa dayalı üretim yapan ve göreceli olarak hala gözlemlenebilen bu topluluklar için müziğin üretildiği alanlar; düğünler, cenaze yerleri, hasat zamanları, mevsim geçişleri, yıl döngüleri, bayramlar, cenazeler, özel eğlenceler (asker uğurlama, sünnet, adak ritüelleri) ve ibadet yerleri olarak karşımıza çıkar. Merkezi alanlarda yaşayan topluluklar için ise müziğin üretim alanları, toprağa dayalı üretim yapan toplulukların mekanlarından farklı olarak; daha organize duran (evler, konuk evleri, düğün salonları, kahvehaneler, kafeler, barlar, pavyonlar, gazinolar vs.) özel alanlardır.

Kurumsal bazda günümüz türkü aktarıcıları (müzik okulları, TRT, Kültür Bakanlığı, belediye koroları gibi) ve bazı akademik çevrelerin türküler ve onların üretildiği mekan ilişkisine dair fikirleri, geleneksel üretim alanları etrafında şekillenir. Ancak değişen toplum düzeni, sosyal ilişki biçimleri, gelenekler, kültürler, gelişen teknoloji ve zaman algısı, müziğin alışıla gelen üretim alanlarını da değiştirmiştir. Diğer yandan küreselleşmeyle, var olan toplumsal dinamikler, üretim ve ticari ilişkiler, yeniden şekillenerek eskisinden farklı yeni kültür alanları ortaya çıkarmıştır. Tomlinson'a (2004) göre küreselleşme ile sahip olduğumuz kültürel deneyimlerimiz ve kimliklerimiz arasında bağlantı değişmiştir. Daha ziyade sanayileşme, teknolojinin gelişimi ve yaygınlaşan kitle iletişim araçlarının kullanımı gibi yeni durumlar; yerel ve kent kültürleri arasında bir etkileşime neden olmuştur. Türkiye'de büyük ölçüde kültürler arası etkileşiminin temelleri, göçler ve radyo-televizyon yayınlarının başlamasıyla atılmıştır. 1920'li yıllarda başlayan TRT yayınları ile toplulukların ihtiyaçları göreceli olarak radyotelevizyon aracılığıyla giderilmiş̧ir. Diğer yandan, toplulukların müzik ihtiyacına cevap veren, sözünü ettiğim müziğin üretildiği yeni mekanlar; yani radyo ve televizyonlar, alışıla gelmiş “türkü"nün mekan ve icrasına yenilikler getirmiştir. Söz gelimi, Yurttan Sesler ${ }^{8}$ topluluğunun radyo yayınları ile türküler yerel dinamiklerinden farklı, yeni bir icra, ağız, şive, hançere, biçimiyle aktarılmıştır (Alpyıldız, 2012, s. 92). Öyle ki Tokel (2002, s. 132) ve Aksoy (2008, s. 202), zamanla TRT'nin yeni icra biçimini tanımlamak için radyo ağzl, TRT a ăgz gibi ifade

\footnotetext{
${ }^{8}$ Muzaffer Sarısözen'in şefliğini yaptı̆̆ı, Vedat Nedim Tör’ün ise ismini verdiği 1947 yılında TRT bünyesinde halk müziği icrası için olușturulmuş korodur.
} 
biçimlerinin ortaya çıktığını ifade eder. Müziğin yerel dinamiklerinden beslenen, ancak bu dinamiklerden bağımsız ortaya çıkan müziğin yeni üretim yerlerindeki yeni icra biçimleri, aydın/kentli toplulukların algılayabileceği bir şeye dönüşmüştür. Dönüşen bu icra biçimleri yalnızca kentlerde yaşayan topluluklara değil, müziğinden beslenilen kırsal alanlarda yaşayan topluluklara da erişmiştir ${ }^{9}$. Son yıllarda, sözünü ettiğimiz popüler kültür ve bu kültürün kullandığı araçlar vasıtasıyla bıraktığı etki; 1920’li yılların başında yayın hayatına başlayan radyo-televizyon yayıncılığının, kırsal alanların müzik kültürü üzerinde bıraktığı etkiden farklı düşünülmemelidir. Radyo ve televizyon yayınları uzun vadede bir kortizon etkisi gibi, güdülen amacının yanı sıra bu türden etkiler de bırakmıştır $^{10}$.

Türkülerin geleneksel üretim sürecinde görebildiğimiz, türküleri üretenlerin bireysel özgünlükleri, yaratım sürecinin önemli ayaklarından birdir. Kendini özgürce ifade edebilen, sözünü çekinmeden söyleyebilen geleneksel türkü üreticileri, yeni dünyanın mekanları arasında sıkışıp kalmış, daha çok denetlenebilir bir organizasyonun parçasına dönüşmüş, yazılı veya yazılı olmayan yeni politik-siyasal ve ekonomik kurallara maruz kalmıştır. Geleneksel türkü üreticilerinden farklı olarak; müziğin üretilip, kültür, dil, coğrafya farklılı̆̆ı gözetmeksizin, müziği daha geniş kitlelere ulaştıran radyo ve televizyonda görevli radyo sanatçılarının kurum içindeki özgünlükleri kısıtlanmıştır. Notaya bağlı icralar, hazır repertuvarlar ve bir devlet kanalı olma hassasiyetleri, bir şef kontrolünde toplu icra gibi bireysel yaratıcılığı engelleyen uygulamalar, kurumsal bağlamda kullanılan ağdalı dil gibi bir dizi neden, radyo sanatçılarının bireysel ifade bütünlüğünü zedeleyen uygulamalardır. Konuyla ilişkili olarak TRT Ankara Radyosu saz sanatçısı Gökhan Karakaya ile yaptığım görüşmede (kişisel iletişim, 07.04.2020), bir kurum sanatçısı olmanın getirmiş olduğu kısıtlamalara dair şunları ifade etmiştir:

Piyasada müzik yaparken daha etkindim. Kendimi bu anlamda çok daha ifade edebiliyordum. Daha özgürdüm. Öğrendiğim, algıladığım bir müzik var. Bunu dışarıda rahatça ifade edebiliyordum. Ancak kurum içinde, toplu bir icranın parçası oluyoruz. Sizin müzikal yeterliliğinizi engelleyen en önemli şeylerden biri, koroda bulunan ve icra kabiliyeti sizden daha düşük bir saz oluyor. Çünkü toplu icralarda, en iyi şekilde icra edene göre değil, en eksik icra edene göre bir uygulama vardır. Örneğin siz bir Yozgat Sürmelisi’ni ne kadar iyi icra ederseniz edin, referans en kötü çalana göre alınır. Öte yandan, TRT’de zamanla bir yarış vardır. Radyo ve televizyonun program akışına bağlı olarak, sürekli bir program içeriğinin hazırlanıp sunulması kaygısı vardır. Maalesef bu yüzden eser üzerine hiç düşünülmemektedir. Bir de, TRT'de gelenekte var olan usta-çırak ilişkisi yok. Yani bir ustamız, öğreticimiz yok orada. Nota bizim tek ustamız.

TRT Ankara Radyosu ses sanatçılarından Reyhan Ediş ile yaptığım görüşmede (kişisel iletişim, 26.04.2020), kurumda ses sanatçısı olarak bulunmanın sağladığı dezavantajlara dair şunları ifade etmiştir:

2015 yılı itibariyle TRT bünyesinde ses sanatçısı olarak çalışmaya başladım. Biz ses sanatçılarının böyle kıymetli bir kurum içinde çalışmaya başlaması ile beraber, bir dolu sorumluluğumuz da oldu. Öncelikli olarak, yerel icra biçimlerine bağlı kalarak, onları bir yerde taklit ederek eser okuyoruz. Ancak, tam anlamıyla eser seçme özgürlüğümüzün olduğunu söylemem çok güç. Genelde bizlere eserler verilir, istenilen süre zarfında

\footnotetext{
${ }^{9}$ Ruhi Su, bir opera sanatçısı olması hasebiyle, almış olduğu opera eğitimini türkü icralarına yansıtan önemli biridir. Ruhi Su'nun bu özel icrası, onu "Basbariton Ruhi Su Türküler Söylüyor" program adıyla radyoya taşır. Alışılagelmiş türkü icralarına kıyasla, özel bir icrası olan Ruhi Su'nun radyoya taşınması, dönemin türkü algısına örnek olması açısından kıymetlidir (Kişin, 2019, s. 26).

${ }^{10}$ Söz gelimi; Muharrem Ertaş ve Neşet Ertaş’ın radyo ve televizyon ekranlarına taşınması ile, Anadolu’nun ücra köşelerinde varlığını sürdüren yerel müzik kültürleri bu iki icra biçimi ile tanışmıştır. Bu kültürler, Ertaş’ın temsil ettiği müzik kültürünün icra biçimi ile tek yönlü etkileşime girmiştir.
} 
icra etmemiz istenir. Diğer yandan, ses sanatçısının eseri ne derece yerele bağlı icra ettiğine pek bakılmaz. En azından bir kısım icracı için öyle. Kaynağa ait bulabildiğimiz ses kayıtlarını referans alıyoruz. Şayet böyle bir kayıt yoksa, doğru okuduğu kabul görmüş ya da doğru okuduğuna inanılan referans bir icracıdan -bunlar genelde eski TRT sanatçıları olur- dinliyorum. Şayet bu da yoksa nota bizim tek göstergemiz oluyor. Bazen hiç bilmediğimiz, duymadığımız bir eser ile karşılaşabiliyoruz. Bu durumlarda, sazların çaldığı biçimde notaya bağlı kalarak seslendiriyoruz. Yurttan Sesler topluluğunda usta-çırak ilişkisi hala devam ediyor gibi. Yani orada okumalarımızı düzelten deneyimli büyüklerimiz var ve faydalanıyoruz oradan. Yoğun bir program temposu içindeyiz bir de. Haftada üç canlı yayın ve provalar oluyor. Kişisel gelişim ve bireysel çalışmalara zaman ayırmak çok güç. Öte yandan, yoğun program akışı içerisinde, tam anlamıyla eserin hakkı bazen verilemiyor. Takdir edersiniz ki, artık her şey elektronik bir sistem üzerinden yapılıyor. Ses sisteminden, televizyon-radyo teknik alt yapısına kadar. İşte bu zorunlu döngü içerisinde de sorunlar yaşıyoruz. Mikrofon ayarından tutun ses dengesine kadar varan geniş bir ölçekte yaşadığımız sorunlar bunlar. Bir de telif problemi var mesela...istediğimiz eseri okuyamadığımız zamanlar oluyor. Ayrıca bazı eserler var, sözlerinden dolayı okuyamadığımız. Genelde siyasal-politik kaygılardan dolayı yasaklı oluyor bunlar. Ton problemi de var. Yani şefin istediği tondan okuyoruz çoğu zaman ve bu tonlar bizim doğal ses aralığımızın dışında oluyor. Tüm bunlar sizin sözünü ettiğiniz kuruma bağlı, ancak bizim icramızı doğrudan etkileyen durumlardır.

Öte yandan, müziğin yeni üretim mekanlarından radyo, televizyon, belediye ve Kültür Bakanlığına bağlı korolarda çalışan saz ve ses sanatçılarının, serbest piyasada müzik yapan diğer meslektaşlarına göre üretkenlikleri de sorgulanmalıdır. Çünkü her iki müzisyen topluluğu arasında tamamıyla ekonomik koşulların belirlediği, üretimin miktarı ve kalitesini belirleyen farklılıklar vardır. Yani, düzenli maaş alan, çalışma saatleri belli müzisyen ile tüm bunlara sahip olmayan müzisyenin müziğin üretimi noktasında durdukları yerin farklı olabileceği, göz ardı edilmemelidir. Türkülerin geleneksel oluşum sürecindeki dönüşümlerinin kurumsal bazda görülen örneklerine, müzik üreticileri ve icracılarının bir araya gelip kurdukları meslek birliklerinde de rastlanmaktadır ${ }^{11}$. Bu meslek kuruluşları türküleri, toplumsal normlarla belirlenmiş var oluş süreçlerinden oldukça farklı bir noktada, koydukları yeni kurallarla yeniden tanımlamışlardır. Artık yazılı olan kurallar, yönetim kurulları ve toplantılar ile belirlenip hangi eserin ve kimin kayda değer olacağına karar vermektedir.

\section{Türkülerde Yöresel Çalgı}

Yöresel çalgıların yerine türküyü farklı çalgılarla icra etme geleneği, milli müzik kültürü yaratma politikalarının bir sonucu olarak karşımıza çıkmaktadır. Ancak, bu uygulamalar zaman içerisinde bazı istenilmeyen sonuçlar doğurmuştur. Bilhassa radyo yayınları ile başlayan süreçte, radyolardaki icra biçimlerinin yörenin ses ve saz sanatçıları tarafından eleştirilmiştir (Çevik, 2012, s. 119). Parlak (2011, s. 422-423) da, "radyocu anlayış" diye tabir ettiği radyonun süre gelen yayın politikalarına eleştirel bakar. Halktan kopuk, kendine özgü bir icra anlayışına dönüşen radyo yayın politikalarının zamanla halk müziği alanında eğitim veren kurumlarını etkilediğini ve buralardaki eğitim sisteminin temelini oluşturduğunu ifade eder.

\footnotetext{
${ }^{11}$ MÜYORBİR (Müzik Yorumcuları Meslek Birliği), MSG (Musiki Eseri Sahipleri Grubu Meslek Birliği) ve MESAM (Türkiye Musiki Eseri Sahipleri Meslek Birliği) bu meslek birlikleri arasında en önemlilerdir.
} 
Radyo yayınlarına dair eleştiriler, şehir ağzı ile türkü söylemeler, türkü sözlerine yapılan müdahaleler ve yöresel çalgı problemi etrafında yoğunlaşmaktadır. Yöresel çalgılar dışında, radyo yayınları ile genel bir icra biçimine dönüşen toplu çalma geleneği de müziğin yöresel dinamiklerinin önüne geçen bir diğer uygulamadır. Bu toplu uygulamalarda; bağlama ailesi, mey, zurna, kaval, davul ve darbuka gibi geleneksel sazların icraların tümünde kullanıldığını görürüz. Zamanla geleneksel bir icra biçimiymiş gibi dönüşen bu yeni uygulamalar, yerel icra biçimlerini de dönüştürmüştür. Toplu icra geleneğinin, bu geleneği taşımayan yerel müzik kültürlerine yansıması da yine TRT başta olmak üzere diğer yayın gereçleri vasıtasıyla gerçekleşmiştir. Kurumsal bazda gördüğümüz toplu icra biçimlerine, kurum dışı alanlarda da rastlanmaktadır. Hınçer (1968, s. 12) ve Paçacı (1999, s. 125), bilhassa 1950 öncesi, sahnelerdeki türkü icralarının şehir müzik kültürünün çalgıları olan ud, keman, cümbüş, kanun gibi sazlarla zaten yapıldığını, 1950’lerde bu tutumun değisşip yerel sazlara dönüldüğü ifade eder.

Orta Anadolu türküleri icralarında kullanılan (Abdallar ve kullandıkları sazları) sazlara bakıldığında, keman ve bağlamanın ön plana çıktığını görürüz. Bağlama üzerinde alt tel grubu la, orta tel grubu la, üst tel grubu ise sol sesine akort edilerek ${ }^{12}$ elde edilen abdal düzeni (Özavc1, 2015, s. 207-208), önceleri Neşet Ertaş'ın da kullandiğ 1 bir düzendir. Ancak Neşet Ertaş sonraları Bayram Aracı'dan etkilenerek, ana düzen (bağlamada alt tel gurubu la, orta tel gurubu re, üst tel grubu ise sol sesine akort edilir ${ }^{13}$ ) kullanmıştır. Zamanla, geniş kitlelere ulaşan bu akort ve çalım şekli, yörenin geleneksel icra biçimiymiş gibi algılanıp, geleneğin yerini almıştır ${ }^{14}$. Parlak bu süreci, Neşet Ertaş’ın çıktığı radyo ve TV'lerde kullandığı bu düzen, yöredeki diğer sanatçılar tarafından benimsenerek gelenek içinde yerini alıp, çağa ayak uydurmuştur, diye ifade etmektedir (Parlak, 2013, s. 130).

Diğer yandan Ersoy’un da sözünü ettiği (2014, s. 938-939) Yurttan Sesler örneğinde olduğu gibi ${ }^{15}$, yerel dinamiklerin merkezi mecralara taşınması ile (konserler, radyo ve televizyon programları, kaset, CD, plak), özel bir yöreye ait türkünün söyleyiş, telaffuz ve çalgısal özelliklerinin nispeten göz ardı edildiği, merkezi bir dil kullanımının, vokal ve çalgısal icra biçiminin (standart da diyebileceğimiz) ortaya çıktığını görürüz. Konuya ilişkin olarak Yener (2011, s. 316), Erol Parlak’ın radyo icralarındaki eksikliklere dair görüşlerini şöyle aktarmıştır:

Neşet Ertaş, parçaları radyoya girerken kaybetti. Muhteşem bir yapı çünkü notasyonu çok güç. Bir türkü bir makamda değil mesela, araştırmacılar o nüansı yakalayamadılar, yazamadılar. Uşşak giden bir türküde hicaz çeşnisi var ama koma nispetleri var, onun yerine trak diye si, si bemol, do diyez yazdılar, o hava kayboldu

\footnotetext{
${ }^{12}$ Adı geçen ton adları, akort sistemindeki aralıkları göstermek için verilmiştir. Akort sisteminde yer alan bu sesler icracıdan icracıya göre değişkenlik gösterebilir.

${ }^{13}$ Adı geçen ton adları, akort sistemindeki aralıkları göstermek için verilmiştir. Akort sisteminde yer alan bu sesler icracıdan icracıya göre değişkenlik gösterebilir.

${ }^{14}$ Konuyla ilgisi olması münasebetiyle, geniş bir icracı alanına sahip, bugünkü adıyla kısa sap bağlamanın varlığına dair bir şeyler söylemek elzemdir. Kemal Eroğlu ile yaptığım görüşmede (kişisel iletişim, 16.04.2020), kısa saplı bağlama olarak (do kesim) bilinen sazın 1980’li yılların başlarında șekillenmeye bașladığını ifade etmiștir. Eroğlu, 1981 yılında ASM'de saz ustası olarak görev yaptığı zaman, Așık Beyhani'nin kardeşi Hüseyin Engin'in atölyeye gelip, kısa saplı bir saz sipariş ettiğini ancak, o zamanlar öyle bir yapım olmadığı için, Eroğlu siparişin bir rızva sazı isteği olduğunu fark ediyor. Ancak, Rıfat Balaban’ın (dönemin radyo sanatçısı) uzun saplı bir sazı alıp, uygun bir yerinden lastikle bağlayıp icra ettiğini söyleyen Eroğlu, o zamanlar si perdesinden kesilmiş (si bemol de olabilir) uzun saplı bir sazın atölyeye geldiğini ifade ediyor. Yusuf Yeniay isimli bir ustanın denemesi olan bu sazın, perde ayarlarını yapılamayıp kendisine getirildiğini söyleyen Eroğlu, tam anlamıyla kısa saplı bağlamanın Arif Sağ'ın Muhabbet 1 albümüyle gün yüzüne çıktığını söylüyor. Arif Sağ'ın albümde kullandığ sazın da fikir babası yine Kemal Eroğlu'dur. Muhabbet albüm serisiyle başlayan sürecin sonunda, bu bağlama formunun kullanımı oldukça yaygınlaşmıştır.

${ }^{15}$ Yurttan Sesler topluluğunun yanı sıra, İstanbul Radyosu'nda türküler icra eden başka topluluklar da vardır: Sadi Yaver Ataman idaresindeki Memleket Havalart Ses ve Tel Birliği Topluluğu; Necati Başaran idaresindeki Şen Türküler Kümesi; Nedim Otyam idaresindeki Yurdun Her Köşesinden Deyişler ve Söyleyişler; Hasan Sözer idaresindeki Karadeniz'den Sesler Topluluğu ve Sadettin Öztorun'un hazırladı̆̆ ' 'Sadettin Öztorun ve Arkadaşları" (Şenel, 1999, s. 117-118, Şenel, 2011, s. 367).
} 
tabii. Bu notayla sanatçılar okudular, sanırım sanatçılar da orijinalden çalışmaya çok yatkın değiller. Ve bunları nasıl okutacağız kaygısı vardır herhalde. Bu kaygı çok önemli, çünkü bütün kültür radyo sanatçısının yeteneği ile sınırlandı. Bu insanlarda şehirli insanlar, nota biliyorlar o zaman bu makbuldü. Ama birçok özellik kayboldu, mahalli sanatçılar isyan ettiler, kendi parçalarının icrasını beğenmediler.

Devlet sanatçısı ünvanı almış, TRT bünyesinde de uzun süre programlar yapmış, geleneği bilen ve gelenek diye atfettiğimiz müzik kültürünün önemli temsilcilerinden olan, aynı zamanda geleneğin temsilcileri ile derin ilişkiler kurmuş Musa Eroğlu'nu özel yapan özellikleridir. Bu minvalde Eroğlu’nun, türkü icralarında başka hangi enstrümanların kullanımının uygun bulup bulmadığı sorusuna verdiği şu cevabı önemlidir:

Yerine göre piyano, çeşitli yaylılar ve gitar gibi Batı enstrümanları da kullanılabilir. Hatta kullanılmalıdır da. Özellikle de gitar! Yahu bu aslında İspanyol Çingenelerine ait bir çalgı. Yani başka bir ulusa ait olsa da sonuçta bir halk çalgısı. Niçin kullanmayalım? Sadece gitarı değil, dediğim gibi, her çalgıyı kullanabiliriz. Ama elbette bunun bir ölçüsü olmalı. Çünkü müzik dediğimiz şey bir kültür meselesidir. Yani teknolojik bir şey değil ki bu, olduğu gibi alıp getirelim. Öz müziğimizi koruyarak, dünyada kullanılan tüm enstrümanlardan faydalanabiliriz. Ama bunun adını “türkü” koyacaksak, geleneksel yapıyı bozmamamız lazım. Mesela benim söylediğim türkülerde, özellikle 1990'lardan beri, evet, bağlama ön plandadır. Ama altta klasik gitar, bas gitar, üflemeli ve yaylı Batı çalgıları da vardır. Kimse rahatsız olmuyor bundan. Rahatsız olmak bir yana, müzikle çok içli dışlı olmayan birileri, çok özel bir amaçla dikkat ederek dinlemezse fark etmiyor bile bunları. Çünkü ona hiç yabancı gelmiyor dinlediği müzik. Çünkü onun bildiği, tanıdığı geleneksel yapı korunmuştur. İnsanlar rahatsız olmadığı gibi, daha çok keyif alıyor bu müzikten. Çünkü daha zengin, daha dolu bir müzik çıkıyor ortaya. İşte bence asıl başarı da burada. Yani hem kendi çalgılarımızı hem de Batılı çalgıları türkü içinde eritebilmeliyiz. Bu, türkünün sınırlarını genişletir. Yolunu aydınlatır. O yüzden diyorum ki, türkü için her çalgı önemlidir (Çevik, 2012, s. 377).

Eroğlu'nun ifadelerine bakıldığında, gelenekte olmayan kendince başarı olarak değerlendirdiği yeni çalgılar ile yakaladığı duyumun, bir ölçüsü olduğunu ifade ediyor. Ancak ölçü olarak, geleneksel bir sazın icra içinde merkezi bir yerde durması olarak belirliyor. Böylelikle "geleneksel yapı”nın bozulmayacağını iddia ediyor. TRT gibi, Eroğlu'nun da geleneğe kazandırdığı yeniliklere bakıldığında, “geleneksel yapı”nın bozulacağına dair oluşan kayg1 eşiğini belirleyen nedenlerin kurumsal ve bireysel değerlendirmelerden öteye geçemeyip net bir biçimde yapılamadığını görüyoruz. Söz gelimi, Yavuz Bingöl’de “ben geleneksel yapıyı böyle korudum, piyano da çaldım icralarımda ama geleneksel sazı da kullandım” deseydi, ya da Ruhi Su da kendi icrasını bu düzlemde bir yere taşısaydı, ortaya çıkan ürün hangi veya kimin geleneksel yapı kriterine göre değerlendirilecekti?

Sonuç itibariyle, türküleri tanımlarken altını çizdiğimiz belli bir bölge, yöre özelliği, karakteristik bir icra, yöresel vokal ve çalgısal icra özelliklerinden bağımsız, membaından farklı, müziğin yeniden üretildiği radyo özelinde türkülerden söz edebiliyorsak şayet, Ankara yeni müzik kültürü veya Karadeniz yeni müzik kültürü örnekleri için de türkü tanımlaması yapılabilir. Geleneğin temsili noktasında büyük anlamlar yüklenen türkünün icra biçimi ve üretiminin, kutsanan bu dinamiklerinden ayrıştırılarak yeni mekânsal, çalgısal ve icraya yansıyan uygulamalarının örnekleri ne kadar türküdür? Sualinin cevabını, bugün Ankara periferi topluluklarının müzik kültürü ve yeni dönem müzik kültürü örnekleri için de veremez miyiz? Benzer biçimde tıpkı radyo-televizyon icralarında olduğu gibi; yerel üretim bağlamından uzaklaşmış, yeni üretim mekanları bulmuş, yerel/mahalli dinamiklerden beslenmiş, yerel dil özelliklerini yansıtan, çalgı ve vokal icra biçimlerinde yerele göndermeler 
yapan, belirli bir topluluk tarafından kabul görmüş, gördüğümüz bu yeni müzik kültürü örnekleri de neden türkü olarak kabul edilmesin? Sorusu akla gelmektedir.

\section{Türkülerde Anonimlik Meselesi}

Başlangıçta bireysel olarak üretilen, ancak zaman içerisinde yapıcısı unutulan eserlerdir. Türküler için yapılan tanımlamalarda anonimlik, türkü özellikleri içerisinde olmazsa olmaz bir seçenek olarak öne çıkmaktadır. Nail Boratav, türküler için anonimliği belirleyici ölçüt olarak kabul eder. Aksi halde, halkın benimseyip türkü kabul ettiği, söz ve ezgi yapısı bir türküye benzeyen ürünleri türkü olarak kabul etmez (Çevik, 2012, s. 19-20). Ancak, Elçin gibi (1993, s. 195), anonim olmayan sözlü halk ezgilerinin de türkü olarak gören araştırmacılar da vardır.

Türkülerde anonimlik meselesi, kelimeyle tam olarak neyin kastedildiği belirtilmemiş halk kavramı ile yakından ilişkilidir. Bilhassa türkü tanımlarında altı ssrarla çizilen noktalardan biridir. Bu noktada "halk sözcüğü ile kast edilenin ve halk olunabilmesi için gerekli olanın ne olduğu” önem kazanmaktadır. Gündelik hayatımızda gördüğümüz halk sözcüğünün yaygın kullanımın getirdiği anlam karmaşası; bizleri, sözcüğün gerçek anlamından uzaklaştıır. Bu karmaşalara, halk otobüsü, halk ekmek, halkçı siyaset adamı, 'halk için', 'halk benim' ile başlayan siyasal söylevler vs. gibi bir dizi örneği sıralayabiliriz. Gündelik hayat içerisinde her bir topluluğu tanımlamak için kullanılan sözcügü̈n kullanımındaki bu çeşitlilik, kısmen haklı gerekçeler içerir. Ancak kültür çalışmalarında sözcüğün kullanımı ile neyin kast edildiği durumu biraz daha karışıktır.

Avrupa'da uzun yıllar boyunca halk sözcüğü ilkel, eğitimsiz, medeni, seçkin, medeniyetten yoksun toplulukları tanımlamak için kullanılmıştır. Benzer yanlış tanımlamalar, Osmanlı'dan günümüze değin süregelen çalışmaların da seyrini değiştirmiştir. Şehirli-köylü, avam-havas, gundi-bajari, kentli-varoş vb. gibi sosyal-sınıfsal tanımlamalar bilhassa saha çalışmalarının niyetini ifşa eden göstergelerdir. Öyle ki, antropologların, etnomüzikologların, müzikologların ve halkbilimi uzmanlarının saha çalışmaları da, yapılan sınıfsal tanımlamalara paralel bir şekilde yoğunlaşmıştır. Folklor oynamak, folklor ekibi ve folklorcu gibi ifadeler, dönemin folklor çalışmalarının Anadolu'nun kırsal alanlarındaki dans üzerine yoğunlaşmış olmalarının bıraktığı yanlış ifade biçimleridir.

Müzikteki halk ifadesi, Osmanlı'nın son dönemlerinde başlayan ve cumhuriyetin kurulması ile devam eden süreçte, ulus-devlet ideolojileri ile paralel gelişip ortaya çıkmış bir arayıştır. Ulus-devlet ve milli bir kimlik yaratma fikri, müziğin yerel dinamiklerinden bağımsız, homojenleşip, köklerinden beslenen tek tip kültür yaratma çabalarına dönüşür. Bu çabalar cumhuriyetin ilk yılarında başlayıp günümüze değin süren müzik politikaları olarak karşımıza çıkar. Ancak, halk sözcüğü ile kurulmaya çalışılan politik münasebetler ile türkü tanımlarında geçen halk sözcüğü arasında anlamsal belirsizlikler vardır. Bu belirsizliklerin temelinde, türkü tanımlarında geçen halk sözcüğü ile neyin ya da kimlerin kastedildiğini kesin bir biçimde betimlenemediğini görürüz. Konuyla ilişkili olarak Parlak, "halk ve anonim süreci" ilişkisini eleştirir. Neşet Ertaş eserlerinin kendi yöresi ve Türkiye'deki farklı icralarının ${ }^{16}$ altını çizerek, anonimleşmenin hangi halk katmanı tarafından yapılacağı sorusunu yöneltir ve bu durumu ütopik bulur. Benzer biçimde Türker Eroğlu da (2017: 80), Türk halk müziği ibaresindeki halk sözcüğü

\footnotetext{
${ }^{16}$ Varyant/çatal/solak/solaklama/başkantı/çeşitleme (Birdoğan, 1988/Notalarıyla Türkülerimiz) adıyla bildiğimiz farklı icra geleneği, yeni icra biçimlerinin doğal süreci değil midir? Örnek: Bugünde Günlerden Cumadır Cuma: Rep no: 1969 ve 1973.
} 
ile neyin kast edildiği, bu sözcük ile nasıl bir topluluğun sınıflandırıldığı hususuna dikkat çekerek bu adlandırmanın eksik olduğunu ifade eder.

O vakit halk nedir? Ne için kullanılmalıdır? Bu soruya ilişkin Dundes görüşlerini şöyle ifade etmektedir:

Peki bir halk grubu ne kadar küçük olabilir? Tarife yönelik olarak benim savunduğum şey şudur ki; bir halk grubu en azından iki şahıstan oluşmalıdır. İki şahsın jest ve mimikler, argo ifadeler vb. gibi kendilerine has bir gelenekler seti geliştirmesi mümkündür. Böyle bir grup kesinlikle çok dar ve sınırlı "halk" olabilir (2012, s. 148).

Ekici (2012, s. 48) de Dundes (1998, s. 143) gibi halkı, herhangi bir sebebe bağlı olarak sahiplenmiş olduğu gelenekler etrafında örgütlenen topluluklar olarak tanımlar. Bu tanım çerçevesinde, kendi arasında bir iletişim biçimi geliştirmiş, kurallar, gelenekler, ritüeller ile birbirlerine bağlı her bir topluluk için üretilmiş gelenekten beslenen, yöresel ifade ve icra biçimi olan yeni müzik kültürü örnekleri de birer türkü değil midir? Sorusu sorulabilir. Nasıl ki, Karadeniz'in bir dağ köyünde yaşayanların bildikleri, oyununu oynadıkları, düğünlerinde, eğlencelerinde söyledikleri, yörenin geleneksel şiir ve telaffuz biçimini yansıtan, yöre sazları ve yörenin karakteristik ezgi yapısını gördüğümüz sözlü-ezgili örnekleri türkü ise; Ankara'nın periferik topluluklarının seslendirip bildiği (yeni Ankara müzik kültürü), yörenin halk şiiri özelliklerini yansıtan, yöreye ait çalg1 ve icra biçimi ile yoğrulmuş, düğün ve eğlencelerinde söyleyip oynadığı, yöresel dil özelliklerini yansıtan sözlü-ezgili örnekleri de türkü olmalıdır. Bu konuda Terzioğlu'nun yeni Ankara müzik kültürü örnekleri üzerinden yaptı̆ğ analiz anlamlı durmaktadır. Terzioğlu (2007, s. 65) Dundes'in halk tanımı üzerinden yola çıkarak yeni Ankara müziğinin; kendi dinamizmi, kuralları ve ritüelize olmuş eğlence biçimleri, görece olarak periferi bir topluluk tarafından kabul gördüğünü ifade etmektedir. Satır (2017, s. 121) ise "Ankaralı Müziği” olarak tanımladığı Ankara yeni müzik kültürünü, müzikolojik bağlamda "yerel sound" biçiminde tanımlamaktadır. Kullanmış oldukları sazın içine "leslie" olarak tanımlanan özel bir efekt sistemi kurulur. Ankara müziğinin olmazsa olmazı bu sound, elektrosaz, kaşık, zil, darbuka ve klavye gibi diğer sazlarla bütünleşmiştir. Orta Anadolu ağzı kullanılan icralar, yöreye geleneksel müziğe dair özellikleri içinde barındırır. Gelenekte görülen müzikli eğlence toplantılarında olduğu gibi, Ankaralı müziği eğlence pratiklerinde de "kostak", "çök”, oturma düzeni, müşteri-mekan ilişkisi, mekan çalışanı kadınlar-müşteri ilişkisi, mekan çalışanı kadınlar ile mekan çalışanı erkekler ilişkisi gibi tanımlayabileceğimiz bir dizi noktada belirli kurallar ile örgütlenmiştir.

Dolayısıyla, kendi kültürel ve coğrafi alanı içinde kabul görmüş, yaygınlaşmış, duydukları, dinleyicinin dinlerken eğlendikleri bu müzik kültürü örneklerinin kime ait olduğunu bilmedikleri (anonim) bu sözlü karakteristik ezgili yapılar da pekâlâ türkü olarak kabul edilebilir.

Süleyman Şenel (kişisel iletişim, 18 Nisan 2020) türkülerdeki anonimlik meselesine iki farklı açıdan bakar. İlk olarak, anonimliğin teknik bir tanımının olduğunu ifade eder. Bu tanım dahilinde anonimliğin, yapıcısı/yakanı belli olmayan türküleri tanımlamak için kullanıldığının altını çizer. Diğer anonimliğin ise, toplumun türküleri zamanla benimseyip, özümseyip, onu yeniden biçimlendirdiği süreci tanımlamak için kullanır.

İlk etapta bireysel bir üretimin sonucu olarak hayat bulan türküler için anonimliğin bu denli kutsanması düşündürücüdür. Geçmişte okur-yazar oranın düşük olması, müziğin yazılmaması, teknolojik yetersizlikler, sözlü kültüre dayalı aktarımın tercih edilmesinin başlıca nedenleri arasında sayılabilir. Tüm bu nedenlerin doğal bir sonucu olarak, türkülerin yapıcılarının bilinememiş kaybolmuşlardır. Esasında araştırmacıların anonimliğe 
yaptıkları bu vurgu da tesadüfi değildir. Şenel'in de ifade ettiği gibi, kast edilen şey türkünün yaratıldığı topluluğun her bir üyesi tarafindan eşit bir mesafede kabul görmüş olmasıdır. Ancak bu kabul için, türkülerin anonimleşme sürecinden geçmesi ne derece önemlidir? Sorgulanmalıdır. Kaldı ki, dinleyici için türkünün kimin tarafından yapıldığının pek bir önemi yoktur. Dinleyici dinlediği türkünün kimin tarafından yazıldığını ve bestelendiğini sorgulamaz. Daha ziyade söyleyen, söyleyenin icra biçimi, icranın tavır ve yöre özellikleri daha önemlidir. Çünkü dinleyici, içinden geldiği müzik kültürüne dair emarelerin icraya ne ölçüde yansıdığı ile ilgilenir. Bir türkünün anonim olup olmaması, "bu türkü anonim mi?" sorusuna verilen bir cevap olmalıdır.

Hızla gelişen ve yayılan teknoloji (ses ve görüntü kayıt cihazları, sosyal medya alanları, televizyon, radyo, cep telefonları), gelişen nota yazımı ve müzik ile alakalı kurulmuş sivil toplum örgütleri (MESAM, MÜYORBİR, MGS gibi) gibi gelişmeler türkülerde anonimlik meselesini sonlandırmıştır. Cahit Öztelli (2002, s. 195) de benzer biçimde bu gelişmelere dikkat çeker. Türkülerdeki anonimliği bir ölçüt görmeyen Öztelli, anonim olan ve olmayan türküler arasındaki farka, her iki gurup türkülerin değişime gösterdikleri direnç noktasından bakar. Yani, yapanı belli türkülerin diğer türkülere göre, daha az değişime uğrayacağını savunur (Çevik, 2012, s. 22). Yeni dünyanın kurallarının anonim türkü üretimi için uygun şartlar sunmaması ile beraber, anonim türkülerin yerini "beste" ezgiler almıştır (Atılgan, 1992, s. 165).

\section{Türkülerde Tema}

Masallar, hikayeler, efsaneler, ninniler gibi türküler de toplumun birer hafızasıdır. Türkülerin bugün gördükleri işlevlerinden farklı olarak, geçmişte gündelik hayatın seyri içerisinde hayatın akışını kolaylaştıran, toplumsal hafızayı taze ve aktarılabilir kılmak, üretildiği topluluğa ait sosyal değerleri taşımak gibi aracı bir yanının olduğu fikri, araştırmacılar nezdinde kabul görür (Gökçe, 1982, s. 11; Başgöz, 2008, s. 144). Gelecek kuşakları bilgilendirmek, onlara deneyimlerini aktarmak, uyarmak, nasihat vermek isteyen toplulukların kullandıkları araçlardır. Sevda türküleri, zanaat havaları, aşk türküleri, kahramanlık türküleri, sohbet havaları, kına ve düğün havaları, gelin güvey türküleri, destanlar, ağıtlar, güldürücü türküler, imece türküler vb gibi konularına göre çeşitlendirilirler. Saymış olduğum konu başlıkları, bireylerin veya toplulukların yaşadıkları, şahit oldukları, toplumda iz bırakan olaylara istinaden yakılmış türkülerden yola çıkılarak oluşturulmuştur. Toplum nezdinde iz bırakmış olaylar ve gelişmeler, zaman içerisinde teknolojik imkanların gelişmesi, okur-yazar oranının artması geçmişte türkülerin üstlendiği- toplumsal hafızanın korunup aktarılması ihtiyacını gidermiştir. Yani, geçmişte masalların, ninnilerin, hikayelerin, fikraların, bilmecelerin, efsanelerin işlevini gördüğü toplumsal bellek yerini, somut olan teknolojik gereçlere bırakmıştır. Filmler, belgeseller, yayınlar, elektronik araç gereç ve internet ortamının sağladığı imkanlar toplumun yeni hafızalardır. Doğal olarak, yeni dönemin türkülerinde işlenen belli başlı konuların azalmasının nedenlerinden biri de, kanaatimce budur. Söz gelimi, toplumu derinden etkileyen 1999 yllında yaşanan 17 Ağustos depremi ile ilgili olarak bir türkü ${ }^{17}$ yakılmamıştır. Çünkü toplum, yaşanan bu hazin olayı hatırlamak için, teknolojik imkanlar dahilinde kendilerine sunulan görsel ve işitsel (belgesel, fotoğraf, video, haber, kitle iletişim araçları ile erişebildikleri anma programları gibi) kolay erişebilir araç ve dokümandan faydalanabilmektedir.

\footnotetext{
${ }^{17}$ Burada türkü diye sözünü ettiğimiz, konu itibariyle 17 Ağustos depremini işleyen, belirli bir topluluk tarafından bilinen, söylenen sözlü bir halk ezgisidir.
} 
Geçmişe oranla, yeni dünyanın dönüşen sosyal, siyasal, kültürel yapısı, kültürler arası iletişim biçimleri, çok daha etkin ve yaygındır. Tüm bu değişim ve dönüşümler, yeni kültür ürünlerinin oluşum süreci, teknik anlamda biçim ve yapılarını doğrudan etkilemiştir. Ahmet Terzioğlu (2000, s. 28) ve Vural (2011, s. 401) da benzer biçimde, değişen toplumsal yapı ve bu yapılara bağlı olarak değişen sosyo-kültürel hayatın, folklor ürünlerine yansıdığını düşünmektedir. Doğal olarak, kültürel olarak dönüşen toplulukların türkülerinde işlenen konular da değişecektir ${ }^{18}$. Söz gelimi, çalgısal dönüşümler (elektronik çalgılar, yeni ses yapıları-sound-), toplu icranın çalgı çeşitliliği (klavye, bas, elektro bağlama gibi), vokal ve çalgı biçimleri ile yenilenmiş Ankara müzik kültürü ve Karadeniz müzik kültürü örneklerinde yer alan tematik olarak sosyal hayatın içerisinde yer eden olaylar ve gelişmeler, yeni sosyal organizasyonların ifade biçimleri, yenilenen söz grupları (“Ah tren kara tren” türkü sözünde geçen tren, “taksi harlayıp geçer” türkü sözünde geçen taksi gibi (Uğurlu, 2009, s. 159-160), ezgi yapıları ile yeni bir müzik kültürü oluşmuştur.

\section{Türkülerde Dil, A ğız, Lehçe}

Türkiye Türkçesi, yirminci yüzyılın başlarından itibaren günümüze değin sadeleşerek gelmiş, Türkiye Cumhuriyeti'nin resmi dil olarak kabul ettiği, Türkçenin bir lehçesidir (Özdemir, 2018, s. 53). Tartışmalarıyla beraber Türkçe, tüm Türk topluluklarının konuştuğu dil çeşitliliğini kapsayan bir tanımlamadır. Türkiye özelinde düşünecek olursak, sıklıkla karıştırılan bir dilin ağız, şive, lehçe yapıları arasında dilin ağız özelliği ön plana çıkmaktadır. Ağız, müzikte karakteristik bir ezgi, söyleyiş biçimini vurgularken, bir yandan da “Aynı dil içinde ses, şekil, söz dizimi ve anlamca farklılıklar gösterebilen, belli yerleşim bölgelerine veya sınıflara özgü olan konuşma dili. (Türk Dil Kurumu Sözlüğü, erişim adresi: https://sozluk.gov.tr)”ni vurgulamak için kullanılır.

Türküler, yöreden yöreye değişen Türkçenin ağızlarına dair önemli ipuçları sunar. Söz gelimi “geliyor musun?” sorusu; bir Malatya türküsünde geliy mısın, Elazığ türküsünde geli misin, Adıyaman türküsünde ise gelor musun'a dönüşebilir. Türkçenin zenginliği olan bu farklılıkların her biri, ait olduğu yörenin müzik kültürü içinde anlam kazanır. Yani, bir müzik kültürüne dair üreteceğiniz sözlü her bir ürün, yörenin dil yapısından bağımsız düşünülmemelidir. Aksi halde, ortaya çıkan şey için, o yöreye aittir demek güçleşir. Yanı sıra dil, müziğin ana üretim araçlarından biridir. Bilhassa, sözlü kültürün bu denli yaygın olduğu Türkiye'de dil, müziğin içindeki en başat rollerden birini üstlenir. Dilin yöreden yöreye göre değişen ağız yapısı, aynı zamanda ezginin de omurgasını da oluşturur. Bir sözcüğün telaffuzu buna bağl1 olarak sözcükte vurgulanan hece, o sözcügün hece sayıs1, sözcüğün taşıdığ1 anlam, sözcüğün cinsiyeti, mahremiyeti, kullanıldığ1 mekan ve tüm bunların dinleyende bıraktığı anlam bir bütün olarak ezginin trafiğini de oluşturur. Örneğin, TRT Repertuvarında 3486 repertuvar numarası ile bulunan Kara Tren Gelmez Mola türküsünün sözlerinde geçen “gelmez mola” ifadesinin "gelmiyor mu?/gelmez mi ola?" dan gelmektedir. Türkçenin dilbilgisi kurallarına uygun olmayan bu kullanım biçiminin yerine dilin yapısına uygun olarak “gelmez mi?” derseniz; sözün hece sayısı ve ağız özelliği değişeceğinden, ezgisini de değiştirmiş olursunuz.

Türkiye Türkçesi, ulus-devlet fikri, milliyetçilik ve kimlik inşasının bir ürünüdür. TRT ve onun öncülük ettiği kurumlar bazında bu çabaların uygulamalarını görebiliriz. Tüm bu çabaların yanı sıra TRT, dil ve türkü arasındaki

\footnotetext{
${ }^{18}$ Ali Osman Öztürk'ün kaleme aldığı “Almanya Türküleri” kitabı, Almanya’ya göç eden Türkiyeli vatandaşların yaktığı türküler üzerine kapsamlı bir araştırmadır. Konuyla ilgisi olması münasebetiyle incelenebilir.
} 
mahrem sınırlarını da belirlemiştir. Söz gelimi, Bahçada Yeşil Çınar adıyla, TRT Repertuvarında 1769 repertuvar numarası ile kayıtlı türkünün sözleri gerçekte; Bahçada Yeşil Hıyar olarak bilinir. Diyarbakır yöresinden derlenen türkünün TRT Repertuvar Kurulundan geçerken, "hıyar" sözcüğünün toplumun ahlak yapısı içinde hoş karşılanmaması nedeniyle, "çınar" sözcüğü ile değiştirilmiştir. Ancak yörede, bu sözcüğün gündelik hayatta kullanımı ile ilgili hiçbir tereddüt bulunmamaktadır. Yöredeki çınar ağacı varlığının azlı̆̆ını göz önünde bulunduracak olursak, türkünün ne derece anlam kaybına uğradığını da tahmin edebiliriz. TRT’nin bu anlamdaki tutumuna dair bir dizi örnek verilebilir. TRT Repertuvarında 2724 repertuvar numarası ile kayıtlı Kar mı Yağmış Şu Harput'un Başına adlı türküde olduğu gibi, türkünün Küçükten bir yar sevim Ermeni bölümü, Küçükten bir yar sevdim yar nenni olarak değiştirilmiştir. Bu müdahale ile türkünün esas var oluş nedeni de ortadan kalkmıştır. Neden yakıldığı, neyi anlattığı da doğal olarak kaybolmuştur.

Örneklerini çoğaltabileceğimiz bir dizi benzer uygulamalar neticesinde yöresel ağız özelliklerinin zamanla kısmen kaybolduğunu, icracı nezdinde önemsenmediğini görürüz. Göreceli olarak, TRT ile başlayan ve zaman içerisinde TRT'nin uygulamalarının kabul görmesiyle yaygınlaşan türkü icralarında merkezi bir dil yapısının benimsenmesi; türkü dinleyenlerin bugün yöresel birçok söz ve telaffuzdan bihaber olmasına neden olmuştur.

Ezgi yapılarının korunup yeni sözlerle bir türkünün icrasına varyant denir. Sözün korunup farklı ezgilerle icrasının mümkün olabileceği gibi, ezginin korunup farklı sözlerle çalınıp söylenmesi de mümkündür. Ancak müziğin üretildiği dil, bu noktada çok önemlidir. Yani her ne kadar ezgi ve ona eşlik eden sazlar aynı olsa da, sözün ait olduğu dil Türkçe değilse; üretilen o yeni şey türkü değildir. Bilhassa farklı dil ve ağızların konuşulduğu Türkiye'de, farklı müzik kültürleri arası etkileşim o kadar yoğundur ki, müzik kültürleri arası ayrımı net bir biçimde ancak dil üzerinden yapabiliriz. Gazimihal (2006, s. 75) bu ayrımı "Azınlık cematlerimizin kendi lisanlarını terennüm eden halk şarkıları” başlığı altında toplayarak yapar. Ancak Gazimihal, Kırgız, Özbek, Tatar, Uygur ve Azerbaycan'ın sözlü halk müziği örnekleri için benzer tanımı yapmaz. Tablo 1'de yer alan bir Kırgızistan halk müziği örneğinde olduğu gibi, diğer Türk topluluklarının ezgileri için de "türkü değildir” diyebilecek miyiz? Sorusu akla gelmektedir. Nitekim Gazimihal, sözünü ettiğim dil farklılığına rağmen Macar, Türkistan, Kırgız, Moğol-Tatar, Şimal Türklerinden, Özbekistan ve Azerbeycan'da derlenen halk müziği örnekleri için "türkü” ifadesini kullanır (Bkz. Gazimihal, 2006, s. 86, 131, 140, 142, 153). Eğer öyleyse, Tablo 2'de yer alan, sözleri hem Türkçe hem de Kürtçe olan Mardin bölgesine ait geleneksel sözlü halk ezgisi için nasıl bir tanımlama yapacağız? Bu örneğe türkü mü diyeceğiz? Yoksa Kürtçe halk şarkısı mı (ya da Kürdi gibi başka bir ifade biçimi) diyeceğiz?

Gazimihal gibi, Öztürk (1994, s. 57) de benzer bir niteleme yapar. Türkü sözcüğünün buradaki anlamı, Türk topluluklarının müzik kültürü örnekleri için kullandığı türkü ifadesi, geleneksel müzik kültürü örneklerini nitelemek için kullanılan türkü sözcüğünden ve Türk'e ait anlamındaki türkü sözcüğünden farklıdır. Daha ziyade politik bir gaye taşıdığı açıktır. Gazimihal ve Öztürk’ün türkü sözcüğüne yüklediği anlam, Türk topluluklarının müzik kültürü örneklerinin genel adı olarak karşımıza çıkmaktadır. 
Tablo 1. Gazimihal (2006, s. 144)

\begin{tabular}{|l|l|}
\hline \multicolumn{1}{|c|}{ Kırgızca } & \multicolumn{1}{c|}{ Türkçesi } \\
Elim, ay!.. & Elim, hey!.. \\
Kızdınıg korgıp & Kızı hor edip \\
Casıkan car ankanınıg & Yapup yaratanın \\
Mal berganedig & Mal verenin \\
Avzına karankanım & Ağzına baktaranın \\
Ay, Elim, Ay, Elim ay, & Ey, Elim, Ey, Elim Ey \\
Sevgimize bara almay, & Sevgilime varamadan \\
Aramand abub ay & Perişan olup ay \\
Turğa tüskân turgay ay & Kafese düşmüş serçe gibi \\
Alakatadım ay & Etrafıma bakıp durdum \\
Elim ay, Elim ay! & Elim hey, Elim hey! \\
\hline
\end{tabular}

Sonuç itibariyle türkülerin sözleri üzerinde yapılan tahribatların ve dil odaklı tasniflerin, türkülerin doğal yaşam sürecinden bağımsız müdahalelerle yeni bir biçime dönüştürüldüğünü görüyoruz. Bir yandan, yapılan bu müdahaleleri olağan kabul edenler, diğer yandan; Mahir Mak'ın doktora tezinde transkripsiyonunu yaptığ 1 (2017, s. 157), her iki topluluğun birlikteliğinin en güzel örneklerinden biri olan, Tablo 2'deki Mardin'in geleneksel sözlü halk ezgisi Sorarım Sorarım Çı Bu Halê te adlı hem Türkçe, hem de Kürtçe söylenen örneklerini türkü olarak tanımlamaktan kaçınmışlardır. 
Tablo 2. Mardin yöresine ait geleneksel Sorarım Sorarım Çibu Halê Te isimli eserin transkripsiyonu

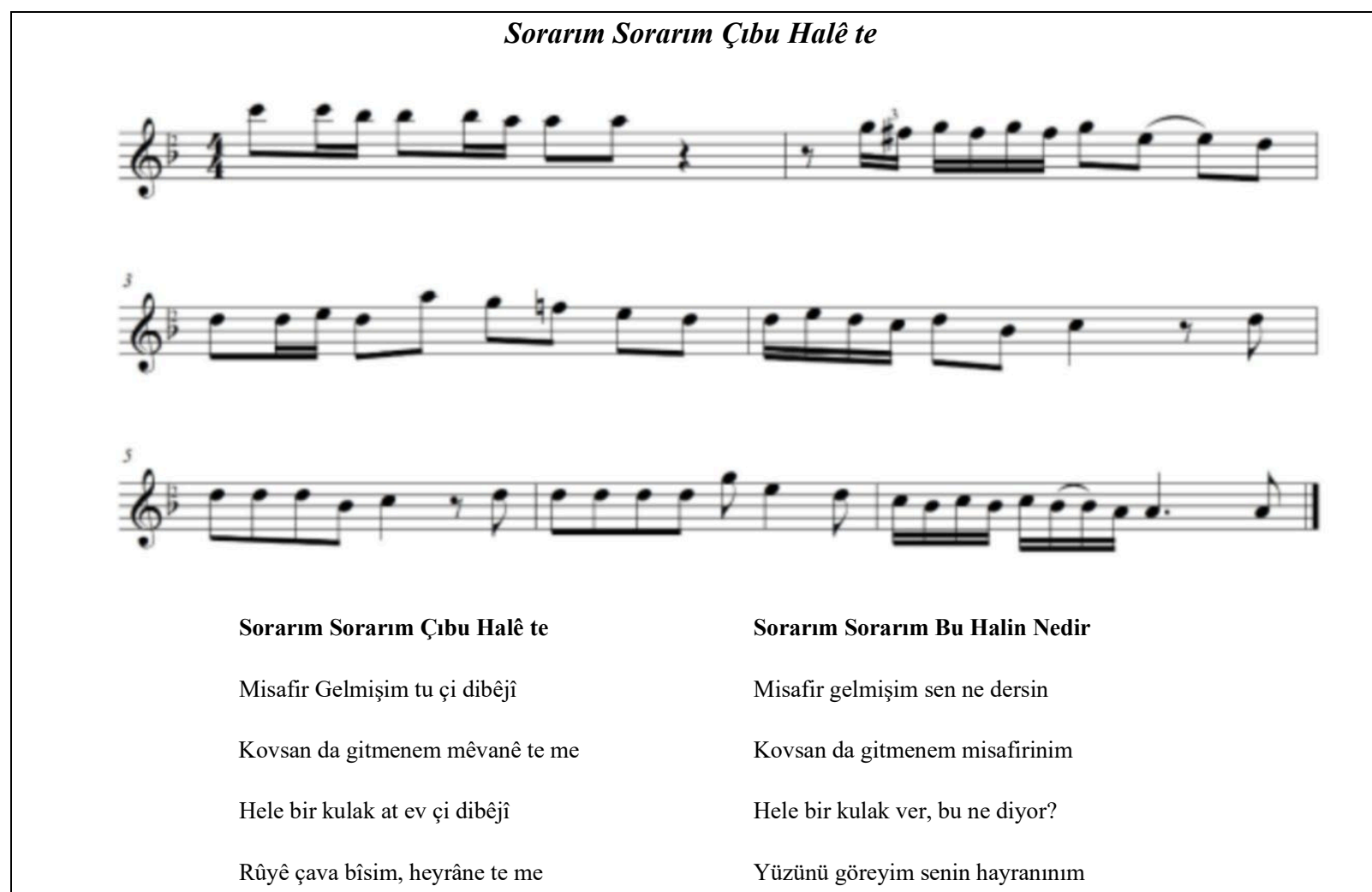

Türkülerde söz, ezginin önünde yer alır. Müzik burada sözün etkisini güçlendiren, aktarımını ve hatırlana bilirliğini sağlayan bir araca dönüşür. Türkü sözlerindeki hece ölçüsü ve kafiye, türkülerin aktarımı noktasında büyük kolaylıklar sunar. Bu hususta söze yapılan olası her müdahale, türkü sözlerinin etkisini de azaltacaktır. Söz gelimi, TRT Repertuvarında 3590 repertuvar numarası ile kayıtlı Çıktım Belan Kahvesine türküsünün sözleri şöyledir:

Çıktım Belan Kahvesine baktım ovaya

Bay Mustafa çağırdı dam’oynamaya

Anlamaz Ormancı yıkar masayı

Söz anlamaz Ormancı çekmiş kafayı

Türkünün sözlerine bakacak olursak, aabb kafiye kalıbı ile yazıldığını görürüz. Halil Atılgan ile yaptığım görüşmede (Görüşme: 01.05.2020), yörede bu türkünün sözlerinin aşağıda yer aldığı gibi, aaaa kalıbıyla söylendiğini ifade etmiştir:

Çıktım Belan Kahvesine baktım ovaya

Bay Mustafa çağırdı dam'oynamaya

Anlamaz Ormanc1 yıkar masaya

Söz anlamaz Ormancı çekmiş kafaya 


\section{Türkülerde Politika}

Türkiye'de ulusal kimlik yaratma -modernleşmenin belki de- adımları arasında türkü derleyiciliği yer alır. Feyzioğlu (2017, s. 54) da, sözlü halk ezgileri ile edebiyatı ilişkilendirerek, derleme çalışmalarının ortak kimlik ve bilinç yaratma çabası olarak değerlendirir. Bu noktada Ersoy’un (2009, s. 268) kolektif bir kültür inşasında ulus-devletlerin halk müziğini kullandıkları yönündeki tespiti anlamlıdır. Diğer yandan cumhuriyet dönemi derleme çalışmalarının altında, batı armoni tarzı ile harmanlanmış, yeni bir halk müziği icrasını savunan Ziya Gökalp tezinin yaygın olduğunu görürüz. Zira, Ziya Gökalp’in söylemleri, halka ve onların üretimlerine yönelen müzik politikalarının bir göstergesi olarak düşünülmelidir. Cumhuriyet dönemi ülke politikalarının geneline bakıldığında, "Türk Milleti” bilincinin oluşturulmasında türküler etkin bir rol üstlendiği, köylü müziği olmaktan çıkıp "Türklerin milli müziği ${ }^{19 "}$ haline geldiğini görebiliriz (Çevik, 2012, s. 67).

Ancak bu çalışma içerisinde ulusallaşmanın, milli bir kültür yaratma, halk müziğine çağdaş-modern bir soluk getirme politikalarının ötesinde, kısmen de olsa TRT kurumunun, dolayısıyla etkisi altında kalan diğer örgütlenmelerin izlediği yayın politikalarına değinilecektir.

TRT her zaman türkülerin derlenip aktarılması noktasında, cumhuriyetimizin önde gelen kurumlarından biri olmuştur. 1920'li yılların sonu itibariyle yayın hayatına başlayan TRT, yayın akışı içerisinde yer verdiği halk müziği programları ile ulusallaşma, milli bir kültür yaratma noktasında önemli hizmetler vermiştir (Şenel, 2009, s. 96). Türkiye'deki geleneksel müziğin serüvenini üç döneme ayıran Ayhan Erol'un ifadelerinde de benzer biçimde, TRT’nin varlığının ne denli anlamlı olduğunu görürüz. Erol bu dönemleri üç evreye ayırır:

1. Cumhuriyetin ilk yıllarından 1950'li yıllara değin geçen süreç: TRT yoluyla otantik icranın kitlelere ulaştırılması ve yerel malzemenin armonize edilmesi,

2. 1960 sonrası dönem: popüler müzik kültürünün halk müziğini kullanmaya başlaması ile beliren yerel müzik dinamiklerinden faydalanan pop müziği örnekleri (Anadolu Rock-Pop),

3. 1990 sonrası: çok kanallı hayat ve devlet tekelinin müzik üzerindeki hakimiyetinin azalması, farklı din ve etnik toplulukların müzikal açıdan kendilerini ifade edebileceği alanların ortaya çıkması (aktaran Çetinkök, 2009, s. 7).

Bilhassa 1940'lı yıllarda Yurttan Sesler'in yayın hayatına başlaması ile, ulus-devlet modelinin çok daha resmi bir düzleme taşındığı söylenebilir (Ersoy, 2014, s. 935). TRT eliyle inşa edilmeye çalışılan milli kültür bilinci, zamanla karşılığını bulmuş ve toplum nezdinde oluşan bugünkü türkü algısının temellerini atmıştır. Ancak, toplumda oluşan bu algının doğruluğu ve yeterliliği yeteri ölçüde tartışılmamıştır.

Mehtap Demir'in etki çerçevesini çizdiği tablo, Yurttan Sesler topluluğunun vesile olduğu türkü algısını görünür kılması noktasında önemlidir. Demir, topluluğu modern ve gelenek kavramları üzerinden tanımlarken; icra biçimine göre dört evreye ayırır. Kurulduğu ilk zamanlar modern bir icra anlayışı ile hareket eden topluluğun, bir sonraki dönem idarecileri tarafından otantik kabul edilip gelenekçi yaklaştıklarını ileri sürer (Demir, 2017, s. 217). Demir, üçüncü kuşak Yurttan Sesler topluluğunun batı sazlarından faydalanıp batı ses sisteminin armonik dilini kullandığını, topluluğun son dönem yapısının ise derlemeler ile erişilen kayıtlar referans alınarak, otantik

\footnotetext{
${ }^{19}$ Mehmet Çevik, 1950 sonrası yöneticilerin, aydın çevrelerin ve bu gurupların etkisi altındaki kentli şehrin nazarında; türküler mili bir değerden ziyade korunması gereken müzelik bir obje olarak görüldüğünü iddia eder (Çevik, 2012, s. 88).
} 
icraya döndüğünü ifade eder. Sarısözen yönetiminde kurulan Yurttan Sesler topluluğunun icra yapısı, devamı niteliğindeki sonraki topluluklar ve diğer eğitim kurumları üzerindeki etkileri, bugünkü post-türkü anlayışına zemin hazırlamıştır. Dolayısıyla, TRT ve onun yayın politikalarının bir sonucu olarak ortaya çıkan türkü algısına bakıldığında, tartışmaların Yurttan Sesler topluluğu merkezli yapılması tesadüfi değildir.

TRT’nin halk müziği icralarıyla başlayan süreç, doğal olmayan uygulamaların yaşandığı bir dizi politik pratiklerle doludur. Söz gelimi, türkülerin halkın tüm yaşantısını konu edebileceğini söyleyen araştırmacı ve yayıncılar, belirli bir topluluğa (halka) ait türkülerin veya belirli konuları işleyen türkülerin ya da yerel dil özelliklerini ve türkülerde geçen bazı sözcüklerin yayınlanmasına mani olmuşlardır. Bekir Karadeniz (2010, s. 17-18) TRT'nin bu tutumuna dair uygulamalarını, Așık Daimi ve Mahzuni eserleri üzerinden izah ederken; içinde haç, Rum, Ermeni geçen türkü sözlerinin yanı sıra, Alevi deyiş̧lerinin (içinde bilhassa Ali ve Haydar geçen) yasaklandığını dile getirir. Musa Eroğlu da, TRT'nin derleme sonrası yaptığı müdahalelere ilişkin TRT Repertuvarında 4386 repertuvar numarası ile kayıtlı şu yemen türküsünü örnek verir;

Kara çadır is mi tutar

Yağlı martin pas mı tutar

Ağlayanım anam bacım

Elin kızı yas mı tutar

olan türkünün sözlerinin repertuvar kurulunun müdahalesinden önce;

Kara çadır is mi tutar

Yağlı martin pas mı tutar

Ağlayalım anam bacım

Osmanlılar yas mi tutar

olduğunu ifade eder (Çevik, 2012, s. 373).

Selçuk Duran icat edilmiş geleneği tanımlarken Aşık Veysel örneğini verir. Onun, cumhuriyet dönemi ulusdevlet ve Türk etnisitesi politikalarındaki aracı görünümüne dikkat çeker. Türkleştirme ve Sünnileştirme politikalarının Veysel'in şiirleri üzerindeki (tematik) yansımalarını, Veysel'in dizelerindeki şu ifadelerle örneklendirir:

Aslım Türk’tür, Elhamdülillah Müslüman

Şükür amentüye etmişiz iman

Kalbimize yakışmaz şirk ile güman

Kalbimiz nur ile dolu sayılır (Duran, 2014, s. 81).

Sonuç itibariyle, yukarıda yer alan örnekte de olduğu gibi türkülerin kendi yaşam döngüsü içerisinde var olan, doğal kültürel seleksiyonunun önüne geçen, toplumsal ve kültürel normlardan uzak, politik müdahalelerle sınırlandırılmış, yapay bir durum söz konusudur. Yani, var olan türkü algısı içinde, geleneksellikle ilişkilendirilerek vurgulanan türkünün doğal döngüsü, TRT eliyle yapay kültürel bir döngüye dönüşür. Bu döngüyü 
belirleyen politik göndermeler içeren kurgusal "halk” kavramıdır. Yaratılmış bu kavram, TRT ve onun temsil ettiği bir nesneden öteye geçemez. Diğer yandan, kurumsal ölçekte yaratılmak istenen türkü algısına karşın, sosyal bir kültürel direnç gösterilmiştir. Arabesk, türkü formu beste, bireysel/ferdi türkü, protest müzik örnekleri, Ankara yeni müzik kültürü, bu direncin örnekleridir.

\section{Bir Tanım Önerisi: "Posttürkü”}

Bu çalışmada, modernizm ve postmodernizm tartışmalarından ziyade; bugünün türkü algısını tanımlayabilmek için kullandığım "posttürkü” kavramını, postmodernizmin argümanları ile ilişkilendirip anlatmayı hedeflemekteyim. Bunu yaparken, TRT ve onun inşa ettiği modern, çağdaş, milli-homojen kültür ve aidiyet gibi modernist ilkeler etrafında şekillenen türkü algısına karşın; tüm bu argümanlara karşı postmodernist anlaşılabilir, kaygısız, siyasal etnik örgütlenmelerden uzak, dili alaycı türkü algısını, periferik toplulukların müzik kültürleri özelinde vurgulamaya çalışacağım.

Postmodernizm üzerine yapılan tartışmalara bakıldığında, kavramın anlamı üzerine fikir birliğine varılamadığını görürüz (Azizağaoğlu ve Altunışık, 2012, s. 36). Ancak genel anlamıyla, Modernizm önüne getirilen post (Latince; sonra, sonraki) ön ekiyle, modernizm sonrası tartışmaları nitelemek için kullanılmıştır (Möngü, 2013, s. 28). Modernizmin bir eleştirisi olarak görenlerin yanı sıra, modernizmin rafine edilmiş bir devamı olarak tanımlayanlar da vardır (Baldan, 2014, s. 38). 20.yüzyılın ortalarından itibaren başlayan postmodernizm tartışmaları, bilhassa 1980'lerden sonra alevlenmiştir. Felsefeden politikaya, tarihten edebiyata, mimariye, sanata varıncaya kadar birçok disiplinde varlık bulan Postmodernizm, zamanla var olan bakış açılarını eleştiren, aracı bir niteliğe bürünmüş̧ür (Erinç, 1994, s. 32). Modernizm vadettiğine karşı çıkan bu akım, modernizm ile arasında organik bir bağ kurar. Dolayısıyla, modernizmin anlatılarını dinlemeden postmodernizm üzerine fikir yürütebilmek imkansızlaşır.

Modernizm, yeni olanı tanımlamak gibi yenilikçi bir eylemi içerir. Modernizmin getirdiği ulus-devlet anlayışı, modern toplum kurgusu, postmodernizm ile birlikte çok kültürlü bir bileşkeye dönüşür. Modernizmin vadettiği uygar ve refah seviyesi yüksek dünya düşüncesi, yaşanan savaşlar, açlık, yoksulluk, çevre kirliliği gibi bir dizi olumsuzluk karşısında sekteye uğramış, bu kaos beraberinde yeni tartışmalar getirmiştir. Modernizmin refah düzeyi yüksek, homojen toplum öngörüsü yerini, postmodernizmin vadettiği kültürel-toplumsal çeşitliliğe, farklılıklara ve zıtlıklara bırakmıştır (Azizoğlu ve Altunışık, 2012, s. 37). Sanat alanında iç savaşların ardından ulus-devlet yapısı içinde olan Amerika, postmodernizm ile 20.yy’ın son çeyreğinde tanışarak çok kültürlü bir yapıya dönen ilk devlettir (Erinç, 1994, s. 38-39). Postmodern sanat algısının eski kıta ülkelerine olan seyahati de tam olarak buradan başlar. Tüketime dayalı postmodern kültür anlayışında birey, var olduğu sosyal hiyerarşi alanından bağımsız, kendisine sunulan tüketim kalıplarını taklit etmeyip, kendi tarzını oluşturur. Modernizm ile gelen özel kültürel biçimler, estetik kaygısı ve belirginlik; postmodernizm ile birlikte yıkılmıştır. Postmodernizm, modernizmin taşıdığı anlayışın karşısında, modernizmin buyruklarından nefret eden, belirsizliği, kurallar bozumunu, melezleşmeyi ve olası dönüşüme açık bir anlayışı getirmiştir. Şaylan da (2002, s. 29) benzer biçimde postmodernizmi, içinde yarışan farklı eğilim ve yaklaşımların yer aldığı sınırları belli olmayan bir alan olarak tanımlar. Postmodern söylemlerin kültürel alanlardaki tartışmaları, Türkiye'de kapsamlı bir biçimde yapılmamasına rağmen; dönüşen siyasal, kültürel, ekonomik, sosyal alanlar kendi iç dinamizmi içerisinde zaten 
bir arayışa girmiştir. Postmodernizmin kültürel taleplerinin başında, etnik kimlik olgusunun ön plana çıktığını görürüz. Ancak buradaki etnik kimlik, siyasi göndermelerden uzak, ortak kökenleri olduğuna inanan insanların oluşturduğu bir yapıdır (Imıl, 2019, s. 65). Postmodernizm, modernizmin elitist bakış açısına karşın, alt-üst kültür ilişkisini ret eden, yerel olanı içine alıp onları yeni ortamlarına taşır (Demirel, 2013, s. 385). Alaycı, sınır bilmez, kültürler arası sınırları ret eden, gelenekten beslenen, anlaşılabilir bir müzik vadeder. Söz gelimi, Ankara’nın periferik toplulukları da bu bağlamda oluşmuş; kendilerini "Uluslu, Angara Bebesi” olarak tanımlamış örgütlenmelerdir.

Diğer yandan, modernizmin aydınlanmacı düşünürleri, geleneğe akıl dışına çıktığını iddia ederek mesafeli yaklaşırlar (Bingöl, 2017, s. 21). Modern sanat anlayışının, gelenek ile olan çatışması buradan kaynaklanır. Ancak tüm bu çatışmaya rağmen, modernliğin gelenek ile sıkı bir bağının olduğu gerçeği yadsınamaz. Aralarındaki bağ, dayatmacı, idealist, homojen görünen modernizmin üstün olduğu, yenilikçi karşllıklı bir etkileşime dönüşür (Bingöl, 2017, s. 24). Tam da burada, bireyin var oluş nedenlerini modernizm göz ardı eder. Bireyi tamamlayan dil, kültür, kimlik gibi bir dizi kavram yerini, bütüncül homojen bir anlayışa bırakır. Modernizm var oluşu gereği, kendi içinde "disiplin altına alma" iradesi gösterir (Alpagut, 2010, s. 120). Ancak postmodernizm bu iradeye karş1 çıktığı gibi, kendi içinde "özgürleşme" söylemini yüceltir. TRT'nin ve onun uygulamalarındaki kuralcı ve standart dil kaygısının yanı sıra, gelenekten beslenen ancak gelenekten farklı bir oluşum ve organizasyon içerisinde oluşu, bu noktada anlam kazanır.

Modernleşme ile başlayan süreç modern toplumu yaratmaya doğru giderken, kültürel çoğulculuğu da sağlamayı hedeflemiştir (aktaran Sağer, Zahal, Gürpınar, 2013, s. 73; Karaduman, 2010, s. 2890). Bu açıdan bakıldığında İrten'in de (2018, s. 112) sözünü ettiği gibi cumhuriyet ile başlayan yeni sürecin içinde ulusallık ve çağdaşlığın olması şaşırtıcı değildir. Osmanlı'nın son dönemlerinde cereyan eden ve Türkiye Cumhuriyeti’nin ilanı ile birlikte batılılaşma olarak görülen modernizmin bir muhatabı da müzik olmuştur (İrten, 2018, s. 99-101). Şayet cumhuriyetin müzik pratiklerinden söz edeceksek, Ziya Gökalp ve söylemlerinin anlam kazanmaya başladığını görürüz. Gökalp'in bu husustaki görüşleri, ortak dil, ulus, homojen kültür etrafinda şekillenir (Parla, 1993, s. 75). Dolayısıyla, halk müziğinin referans alınarak, ulus bilincinin yaratılma çabası bu anlamda tesadüfi değildir. Zira bu dönemde, Gökalp'in fikirleri ile sentezlenen müzikal reformlar bilhassa halkevleri ve radyolar ile halka ulaştırılmaya çalışılmıştır (İrten, 2018, s. 116). TRT ve TRT’nin öncülük ettiği diğer kurumlar ölçeğinde bu çabalar, kültürün yerel dinamiklerinden beslenen ancak modernizmin sınırlarını çizdiği yeni organizasyonlara dönüşmüştür. Söz gelimi Yurttan Sesler topluluğunun gösterdiği istikameti, müzik eğitim kurumları, halk evleri ve diğer devlet kurumları izlemiştir. Ancak 20.yy’ın ortalarından itibaren gördüğümüz sosyal, siyasal, kültürel ve ekonomik hareketler, bu alanlardaki dönüşümü zorunlu kılmıştır. TRT kurumunun yaratmaya çalışıtı̆ı milli bilinç, kültür ve kimlik gibi çabaları, postmodernizmin direnci ile karşılaşmıştır. Bu çalışmada, modernizm ve postmodernizm savaşından bağımsız, TRT ve onun yayın anlayışının oluşturmaya çalışsığı "türkü algısı", modernizmin bir metaforu olarak kabul edilmiştir. TRT'nin uygulamalarına karşın, zaman içerisinde gelişen direnç, postmodernizmin iddialarında olduğu gibi yeni bir türkü algısına dönüşmüştür. TRT'nin öncülüğünü yaptığı modern türkü anlayışının parametreleri, değişen, dönüşen kültürel dünya içinde postmodernizmin dinamiklerine zemin hazırlamıştır. Dolayısıyla bu çalışmada, TRT'nin “modern türkü anlayışı”na karşın, yeni dönemin müzik kültürü örnekleri “posttürkü” olarak tanımlanmıştır. 


\section{Sonuç Yerine}

Cumhuriyet dönemi modernleşmesinin kültür alanındaki izlerini sürebilmemizde, TRT anlamlı bir yer tutar. Çağın, ulus-devlet, homojen kültür, dil, kimlik yaratma çabaları, radyo-televizyon yayınlarına yansır. Bu bağlamda derlenen ezgiler, modernizmin savlarına paralel, yeni mekanlarında, standart bir dilin ve çalgısal icranın kullanıldığı, döneminin mevcut politik ihtiyaçlarına cevap veren, yerel icralardan nispeten bağımsız, doğal olmayan müdahalelerle yeniden üretilmişlerdir. TRT tam da bu noktada önemli bir yere sahiptir. Bünyesinde yer verdiği türkü yayınları ile, cumhuriyetin kültür politikalarının devamlılığını sağlaması münasebetiyle anlamlıdır. Gerek türkü icra biçiminde getirdiği yenilikler, gerekse yetiştirdiği sanatçı profili, ve kapsamlı türkü yayını yapan kanal ve programları ile Türkiye'de bir türkü algısı yaratmıştır. TRT’nin öncülüğünü yaptığı bu anlayış, zaman içerisinde faaliyet gösterecek olan müzik eğitim kurumları ve diğer kurumlar (halk evleri, dernekler, vakıflar, özel müzik kursları, bakanlık ve belediye koroları gibi) nezdinde kabul görmüştür. Ancak izlenen kültür politikaları, zaman içerisinde dönüşen, değişen sosyal, ekonomik, siyasal ve kültürel parametreler karşısında bir direnç ile karşılaşmıştır.

Modernizmin ortaya attığı ulus-devlet, kimlik, homojen kültür yaratma çabaları, 20.yüzyıl ortalarındaki Türkiye'nin kurumsal ilkeleridir. TRT ve TRT’nin öncülük ettiği diğer kurumlar ölçeğinde bu çabalar, kültürün yerel dinamiklerinden beslenen ancak modernizmin sınırlarını çizdiği yeni organizasyonlara dönüşmüştür. Söz gelimi Yurttan Sesler topluluğunun gösterdiği istikameti, müzik eğitim kurumları, halk evleri ve diğer devlet kurumları izlemiştir. Ancak 20.yüzyılın ortalarından itibaren gördüğümüz sosyal, siyasal, kültürel ve ekonomik hareketler, bu alanlardaki dönüşümü zorunlu kılmıştır. Postmodern söylemlerin kültürel alanlardaki tartışmaları, Türkiye'de kapsamlı bir biçimde yapılmamasına rağmen; dönüşen siyasal, kültürel, ekonomik, sosyal alanlar kendi iç dinamizmi içerisinde zaten bir arayışa girmiştir. TRT'nin öncülüğünü yaptığı modern türkü anlayışının parametreleri, değişen, dönüşen kültürel dünya içinde postmodernizmin dinamikleri ile örtüşmeye başlamıştır. Dolayısıyla bu çalışmada, TRT’nin “modern türkü anlayışı”na karşın, yeni dönemin müzik kültürü örnekleri “posttürkü” olarak tanımlanmıştır.

Kendini özgürce ifade edebilen, sözünü çekinmeden söyleyebilen geleneksel türkü üreticileri, yeni dünyanın mekanları arasında sıkışıp kalmış, daha çok denetlenebilir bir organizasyonun parçasına dönüşmüş, yazılı veya yazılı olmayan yeni politik-siyasal ve ekonomik kurallara maruz kalmıştır.

Geleneksel türkü üreticilerinden farklı olarak; müziğin üretilip, kültür, dil, coğrafya farklılığg gözetmeksizin, müziği daha geniş kitlelere ulaştıran radyo ve televizyonda görevli radyo sanatçılarının kurum içindeki özgünlükleri kısıtlanmıştır. Notaya bağlı icralar, hazır repertuvarlar ve bir devlet kanalı olma hassasiyetleri, bir şef kontrolünde toplu icra gibi bireysel yaratıcılığı engelleyen uygulamalar, kurumsal bağlamda kullanılan ağdalı dil gibi bir dizi neden, radyo sanatçılarının bireysel ifade bütünlüğünü aynı zamanda türkülerin doğal yapısını zedeleyen uygulamalar olmuşlardır.

Öte yandan, müziğin yeni üretim mekanlarından radyo, televizyon, belediye ve Kültür Bakanlığına bağlı korolarda çalışan saz ve ses sanatçılarının, serbest piyasada müzik yapan diğer meslektaşlarına göre üretkenlikleri ekonomik nedenlere bağlı olarak değişkenlik göstermektedir. Düzenli maaşlı devlet sanatçıları ile piyasa sanatçılarının üretim noktasındaki çabaları farklıdır. 
Türkü tanımlamalarında geçen halk sözcüğü ile neyin kast edildiği, bu sözcük ile nasıl bir topluluğun tanımlandığı noktasında net bir ifade yoktur. Bu belirsizlik anonimlik ve türkülerin belirli bir topluluk tarafından sahiplenilmesi gerekliliği tartışmalarını doğurmuştur.

Türkülerin halkın tüm yaşantısını konu edebileceğini söyleyen araştırmacı ve yayıncılar, belirli bir topluluğa (halka) ait türkülerin veya belirli konuları işleyen türkülerin ya da yerel dil özelliklerini ve türkülerde geçen bazı sözcüklerin yayınlanmasına mani olmuşlardır. TRT, bu anlamda bir dizi uygulamaya sahiplik etmesi noktasında özel bir yere sahiptir.

Halktan kopuk, kendine özgü bir icra anlayışına dönüşen radyo yayın politikalarının zamanla halk müziği alanında eğitim veren kurumlarını etkilediğini ve buralardaki eğitim sisteminin temelini de oluşturmuştur.

Radyo yayınlarına dair eleştiriler, şehir ağzı ile türkü söylemeler, türkü sözlerine yapılan müdahaleler ve yöresel çalgı problemi etrafinda yoğunlaşmaktadır. Yöresel çalgılar dışında, radyo yayınları ile genel bir icra biçimine dönüşen toplu çalma geleneği de, müziğin yöresel dinamiklerinin önüne geçen bir diğer uygulamadır.

İlk etapta bireysel bir üretimin sonucu olarak hayat bulan türküler için anonimliğin bu denli kutsanması düşündürücüdür. Geçmişte okur-yazar oranın düşük olması, müziğin yazılmaması, teknolojik yetersizlikler, sözlü kültüre dayalı aktarımın tercih edilmesi, sözünü ettiğimiz anonimliğin başlıca nedenleri arasında sayılabilir. Şenel'in de ifade ettiği gibi, anonimlikle kast edilen şey türkünün yaratıldığı topluluğun her bir üyesi tarafindan eşit bir mesafede kabul görmüşs olmasıdır. Ancak bu kabul için, türkülerin anonimleşme sürecinden geçmesi ne derece önemlidir? Sorgulanmalıdır. Hızla gelişen ve yayılan teknoloji (ses ve görüntü kayıt cihazları, sosyal medya alanları, televizyon, radyo, cep telefonları), gelişen nota yazımı ve müzik ile alakalı kurulmuş sivil toplum örgütleri (MESAM, MÜYORBİR, MGS gibi) gibi gelişmeler türkülerde anonimlik meselesini sonlandırmıştır. Geçmişte masalların, ninnilerin, hikayelerin, fikraların, bilmecelerin, efsanelerin işlevini gördüğü toplumsal bellek yerini, somut olan teknolojik gereçlere bırakmıştır. Filmler, belgeseller, yayınlar, elektronik araç gereç ve internet ortamının sağladığı imkanlar toplumun yeni hafızalardır. Doğal olarak, yeni dönemin türkülerinde işlenen belli başlı konuların azalmasııın nedenlerinden biri de, kanaatimce budur.

Sonuç itibariyle, yukarıda yer alan örnekte de olduğu gibi türkülerin kendi yaşam döngüsü içerisinde var olan, doğal kültürel seleksiyonunun önüne geçen, toplumsal ve kültürel normlardan uzak, politik müdahalelerle sınırlandırılmış, yapay bir durum söz konusudur. Bu açıdan bakıldığında, TRT'nin yaratmış olduğu yapay kültürel döngü içindeki türkülerin, yeteri ölçüde sorgulanmayışları ve bu denli referans alınmaları etraflıca tartışılmalıdır. 


\section{Kaynakça/References}

Aksoy, B. (2008). Geçmişin Musiki Mirasına Bakışlar. İstanbul: Pan Yayınları.

Alpagut, U. (2010). Dünya Müziğinde Son Yirmi Yıla İlişkin Değerlendirmeler: Hollanda Örneği, Folklor Edebiyat, 62, 117-133.

Alpyıldız, E. (2012). Yerelden Ulusala Taşınan Müzik Belleği ve Yurttan Sesler, Milli Folklor, 24, 84-92.

Ambros, G. E. (ty). Türkü. Encyclopadia of Islam (Second Edition) içinde, erişim tarihi: 26.02.2020, Erişim adresi:https://referenceworks.brillonline.com/entries/encyclopaedia-of-islam-

2/turkuSIM_7646?s.num=0\&s.f.s2_parent=s.f.book.encyclopaedia-of-islam-2\&s.q=türkü

Arat, R.,\& R. (1986). Eski Türk Şiiri. Ankara: Türk Tarih Kurumu.

Atalay, B. (1992). Divanü Lügati’t-Türk Tercümesi. İstanbul: Atatürk Kültür Dil ve Tarih Yüksek Kurumu Yayınlar1.

Atılgan, H. (1992). Halk Müziğimizde Anonimlik ve Beste Meselesi. Türk Halk Müziğinde Çeşitli Görüşler içinde, s.163-173, Ankara: Kültür Bakanlığı.

Azizağaoğlu, A.,\& Altunışık R. (2012). Postmodernizm, Sembolik Tüketim ve Marka. Tüketici ve Tüketim Araştırmaları Dergisi, 2, 33-50.

Baldan, O. (2014, 17-18 Kasım). Üretim Tüketim ilişkileri, Eser Sahipliği ve Telif Hakları Açısından Modernite, Postmodernite, Gelenek. II. İzmir Ulusal Müzik Sempozyumu Bildirileri içinde, İlhan Ersoy ve diğerleri (Yay.haz), s.33-40. İzmir: Meta Basım.

Başgöz, İ. (2008). Türkü. İstanbul: Pan Yayıncılık.

Behar, C. (2008). Musıkiden Müziğe-Osmanll/Türk Müziği: Gelenek ve Modernlik. İstanbul: Yapı Kredi Yayınları.

Bingöl, U. (2017). Postmodernizm ve Gelenek. Hikmet Akademik Edebiyat Dergisi, 7, 20-33.

Birdoğan, N. (1998). Notalarıla Türkülerimiz. İstanbul: Özgür Yayın Dağıtım.

Boratav, P. N. (1978). 100 Soruda Türk Halk Edebiyatı. İstanbul: Gerçek Yayınevi.

Boratav, P. N. (1982). 100 Soruda Türk Halk Edebiyatı. İstanbul: Gerçek Yayınevi.

Burç, U. Ö. (2009). TRT Repertuvarındaki Türkü Sözlerinin Konu, Tür ve Biçim Açısından İncelenmesi (Yayımlanmamış yüksek lisans tezi), Afyon Kocatepe Üniversitesi Sosyal Bilimler Enstitüsü, Afyon.

Büyükturan, N. (2019). Alanda Çalışmak Derlemecinin Er Meydanı. Bir Dünya Müzik TRT Aylık Müzik Dergisi, $45,22-23$.

Büyükturan, N., (2019), Mehmet Özbek: Türkü Peşinde Bir Ömür. Bir Dünya Müzik TRT Ayllk Müzik Dergisi, 45, 14-16.

Büyükturan, N., (2019), Türkü Sarrafi: Yücel Paşmakçı. Bir Dünya Müzik TRT Aylık Müzik Dergisi, 45, 16-18.

Canbaz, F. (2015). Türkü ve Türkü-Barlar. Milli Folklor, 59, 49-52. 
Çetinkök, A. (2009). Türk Halk Müziği uyanışının Kitle Medyası Bileșeni Olarak “Türkü radyo” (Yayımlanmamış yüksek lisans tezi), Dokuz Eylül Üniversitesi Güzel Sanatlar Enstitüsü, İzmir.

Çevik, M. (2012). Türkü Kültüründe Değişim Süreci ve Musa Eroğlu (Doktora tezi), Gazi Üniversitesi Sosyal Bilimler Enstitüsü, Ankara.

Çobanoğlu, Ö. (2010). “Türkü” Olgusu Bağlamında 'Türkü’ ve 'Şarkı’ Terimlerinin Etimolojisini Yeniden Tanımlama Denemesi. Türk Yurdu Dergisi, 269. 46-49.

Daloğlu, Y. (2017). Folklor Dersleri, Türkiye’de Musiki Folkloru. İstanbul: Opus Yayıncılık.

Demirel, E. (2010). Müzikte Postmodernizm. Fine Arts, 4, 379-388, http://dx.doi.org/10.12739/NWSA.2013.8.4.D0141.

Dilçin, C. (2000). Örneklerle Türk Şiir Bilgisi. Ankara: Türk Dil Kurumu.

Dirican, Ü. (2019). Prof. Dr. Erol Parlak ile Derlemeciliğe Akademik Bir Bakış. Bir Dünya Müzik TRT Aylık Müzik Dergisi, 45, 18-20.

Dizdaroğlu, H. (1968). Halk Şiirinde Türler. Türk Dili Dergisi, S.207, s.186-293.

Dizdaroğlu, H. (1969). Halk Şiirinde Türler. Ankara: TDK Yayınları.

Dundes, A. (1998). Halk Kimdir? Çev. Metin Ekici. Milli Folklor, 37, 139-153.

Duran, S. (2014). Aşıklık Geleneğinden Protest Müziğe Ali Asker Örnĕgi (Yayımlanmamış yüksek lisans tezi), Mimar Sinan Güzel Sanatlar Üniversitesi Sosyal Bilimler Enstitüsü, İstanbul.

Duygulu, M. (2014). Türk Halk Müziği Sözlüğü, Ankara: Pan Yayıncılık.

Ekici, M. (2012). Halk, Halk Bilimi ve Halk Bilgisi Üzerine Bir Deneme. Milli Folklor, 45, 2-8.

Elçi, A. (1997). Muzaffer Sarısözen Hayatı, Eserleri ve Çalışmaları. Ankara: Kültür Bakanlığı Yayınları.

Elçin, Ş. (1993). Halk Edebiyatına Giriş. Ankara: Akçağ Yayınları.

Elçin, Ş. (1997). Halk Edebiyatı Araştırmaları-1. Ankara: Akçağ Yayınları.

Emnalar, A. (1998). Tüm Yönleri ile Türk Halk Müziği Nazariyatı. İzmir: Ege Üniversitesi Basımevi.

Erinç, M. S. (8 Haziran 1994). Postmodernizm’in Tanımı. Anadolu Üniversitesi Eğitim Fakültesi’nde Verilen $\begin{array}{lll}\text { Konferans } & \text { Metni, Erișim }\end{array}$ adresi:https://earsiv.anadolu.edu.tr/xmlui/bitstream/handle/11421/1059/103412.pdf?seque

Eroğlu, T. (2017). Türkü Nedir?. Kesit Akademi Dergisi, 7, 78-91.

Ersoy, İ. (2009). Türkiye'de Uluslaşma Sürecinde Bir Simge Olarak 'Bağlama'. Motif Halk Oyunları Eğitim ve Öğretim Vakfı, Halk Müziğinde Çalgılar Uluslararası Sempozyumu Bildirileri içinde, 268-278, İstanbul: Motif Vakfi Yayınları.

Ersoy, İ. (2014). Türk Halk Müziğinin Yeniden Üretimi/İnşası: Ulusal Kaynaştırma Projesi Olarak "Yurttan Sesler” Topluluğu. International Journal Of Human Sciences, 2, 31-947. 
Feyzioğlu, N. (2017). İdeoloji, Mantalite, Tarih ve Anlatı Kavramları Çerçevesinde Türkü (Halk Şarkısı) Biçimi. İn̈nü Üniversitesi Kültür ve Sanat Dergisi, 3, 49-63.

Gazimihal, M. R. (1961). Musiki Sözlüğü. İstanbul: Milli Eğitim Basımevi.

Gazimihal, R. M. (2006). Anadolu Türküleri ve Musiki İstikbalimiz. (M.Salih Ergan ve Ahmet Şahin Ak, Çev.). İstanbul: Ötüken Yayınları.

Gökçe, E. (1982). Eğin Türküleri. Ankara: Yaba Yayınları.

Hınçer, İ. (1968). Türkiye’de Folklor Hareketleri. TFA 20. Yll Özel Sayısı, 11-13.

Hoşsu, M. (1997). Geleneksel Türk Halk Müziği Nazariyatı. İzmir: Peker Ambalaj ve Kağıt Sanayi.

Imıl, M. (2019). Modernizm Sonrası Ulus Kimlik ve Bileşenleri. SDÜ Fen-Edebiyat Fakültesi Sosyal Bilimler Dergisi, 48, 61-72.

İrten, S. (2018). Gelenek ve Modernizm İkileminde Bir Ses(Sizlik): Musiki İnkılabı. Online Journal of Music Sciences, 2, 98-121.

Karadeniz, B. (2010). Türkülere Giriş. İstanbul: Kara Mavi yayınları.

Karaduman, S. (2010). Modernizmden Postmodernizme Kimliğin Yapısal Dönüşümü Journal of Yaşar Üniversitesi, 17, 2886-2899.

Kişin, Y. (2019). Halk Türkülerinde Protest Olgu ve Ruhi Su (Yayımlanmamış yüksek lisans tezi), Cumhuriyet Üniversitesi Sosyal Bilimler Üniversitesi, Sivas.

Köprülü, M. F. (1993). Türk Edebiyatında İlk Mutasavvıflar, (I.Baskı). Ankara: Diyanet İşleri Başkanlı̆̆ı Yayınları.

Mak, M. (2017). Müziğin Çokkültürlü Kodları: Mardin (Doktora tezi), İstanbul Teknik üniversitesi Sosyal Bilimler Enstitüsü, İstanbul.

Möngü, B. (2013). Postmodernizm ve Postmodern Kimlik Anlayışı. Atatürk Üniversitesi Sosyal Bilimler Enstitüsü Dergisi, 2, 27-36.

Onay, A. T. (1996). Türk Halk Şiirinin Şekil ve Nev'i. haz. Cemal Kurnaz, Ankara: Akçay Yayınları.

Özavcı, K. (2015, Mayıs). Orta Anadolu Türküleri ve Bozlak İcrasında Abdal Düzeni Kullanımının Azalması ve Sebepleri. I. Uluslararası Müzik ve Dans Kongresi içinde, Diyarbakır.

Özbek, M. (1981). Folklor ve Türkülerimiz. İstanbul: Ötüken Yayınları.

Özbek, M. (1998). Türk Halk Müziği El Kitabı I Terim Sözlüğü. Ankara: Atatürk Kültür Merkezi Başkanlığı Yayınları.

Özbek, M. (2009). Türkülerin Dili. Ankara: Ötüken Yayınları.

Özbek, M. (2010). Türkü Deyip Geçme Tan1. Türk Yurdu Dergisi, 269, 53.

Özdemir, C. (2018). Tarihi Gelişi Bakımından Türkiye Türkçesi. Alatoo Academic Studies, 2, 52-57.

Öztelli, C. (2002). Evlerinin Önü Türküler. (İlk basım:1972), İstanbul: Özgür yayınları. 
Öztuna, Y. (1976). Türk Musikisi Ansiklopedisi II. İstanbul: Milli Eğitim Basımevi.

Öztuna, Y. (2006). Türk Musikisi Ansiklopedik Sözlü̈̆̈̈̈. Ankara: Orient Yayınları.

Öztürk, A. O. (Erişim tarihi: 06.04.2020), Konya Türkülerinin “Kimlik Tanımı Bağlamında Sosyal İşlevi”. Erişim adresi: http://www.turkuler.com/yazi/konyaturkulerinin.asp

Öztürk, A. O. (1994). Azerbaycan Halk Türküleri. Milli Folklor, 3/24, 57-58.

Paçacı, G. (1999). Cumhuriyet Döneminde Halk Müziği. Cumhuriyet’in Sesleri (içinde), İstanbul: Tarih Vakfı Yayınları.

Parla, T. (1993). Ziya Gökalp, Kemalizm ve Türkiye'de Korporatizm. İstanbul: İletişim.

Parlak, E. (2011). “Türkiye'de Türk Halk Müziği Çalışmalarının 100. Yılına Doğru Bir Durum Tespiti” Adlı Metin Hakkında Rapor. Evrim Ulusan Öztürkmen (Ed.), Türk Halk Bilimi Çalışmaları Kurultayı Bildirileri içinde, s.422-424, İstanbul: Motif Vakfi Yayınları.

Parlak, E. (2013). Garip Bülbül Neşet Ertaş 2. İstanbul: Demos Yayınları.

Pelikoğlu, M. C. (2012). Geleneksel Halk Müziği Eserlerinin Makamsal Açıdan Adlandırılması. Erzurum: Atatürk Üniversitesi Yayınları.

Sağer, T., Zahal, O., \& Gürpınar, E., (2013). Cumhuriyeti' in İlk Yıllarında Müzikte Modernleşme Hareketleri ve Müzik Politikaları (1923-1952). İnönü Üniversitesi Uluslararast Sosyal Bilimler Dergisi, 2, 71-89.

Sakaoğlu, S. \& Alptekin, A. B. (2006). Anonim Halk Edebiyatı. Türk Edebiyat Tarihi IV, ed. Talat Sait Halman vd, s.587-614, Ankara: Kültür Bakanlı̆̆ı.

Satır, Ö. S. (2017). Yeni Ankaralı Müziğinin Tanımı Üzerine. Sosyoloji Dergisi, 38, 107-130.

Şaylan, G. (2002). Postmodernizm. 2.Baskı. Ankara: İmge Kitabevi.

Șenel, S. (1999). Cumhuriyet Dönemi’nde Türk Halk Müziği Araştırmaları. Folklor/Edebiyat,17, 99-128.

Şenel, S. (2009). Yücel Paşmakçı ile Türküler Üzerine Söyleşi. İstanbul: İstanbul Teknik Üniversitesi Türk Musikisi Devlet konservatuarı Yayınları 2.

Şenel, S. (2011a). Türkünün Tanıkları ve Türkü Algısındaki Değişimler. Kadir Pürlü (Ed.). Kültürümüzde Türkü Sетроzуити içinde, 65-92, Sivas.

Şenel, S. (2011b). Türkiye'de Türk Halk Müziği Çalışmalarının 100. Yılına Doğru Bir Durum Tespiti. Evrim Ulusan Öztürkmen (Ed.). Türk Halk Bilimi Çalışmaları Kurultayı Bildirileri içinde, 342-414, İstanbul: Motif Vakfi Yayınları.

Terzioğlu, A. (2000). Türk Folkloru İçinde Halk Oyunları Oynayanların Psiko-Sosyal Özellikleri ve Oyunların Şahsiyet Gelişimine Etkisi. İstanbul: Milli Eğitim Bakanlığı Yayınları.

Terzioğlu, Ö. (2007). Çağdaş Kentte Türkü ve Ankaralı Folkloru. Milli Folklor, 75, 60-75.

Timur, K. (2017). Kural Tanımayan Bir İdeoloji: Postmodernizm. Hikmet Akademik Edebiyat Dergisi, 7, 1-9.

Tokel, B. B. (2000). Neșet Ertaș Kitabı. Ankara: Akçă̆ Yayınları. 
Tomlinson, J. (2004). Küreselleşme ve Kültür. İstanbul: Ayrıntı Yayınları.

Tüfekçi, N. (1995). Türk Halk Müziği. Cumhuriyet Dönemi Türkiye Ansiklopedisi içinde, C.6,1482-1488, İstanbul: İletişim Yayınları.

Uğurlu, N. (2009). Folklor ve Etnografya - Halk Türkülerimiz. İstanbul: Örgün Yayınevi.

Vural, F. G. (2011). Türk Kültürünün Aynası: Türküler. e-Journal of New World Sciences Academy, 6, 397-411.

Yakıc1, A. (2013). Halk Şiirinde “Türkü”. Ankara: Akçağ Yayınları.

Yazıcı, R. (1995). Türkülerimizin Türklügü. Kayseri: Erciyes.

Yener, A. S. (2011). Türkü Derlemelerinde Yapılan Yanlışllklar ve Düzeltilmesine İlişkin Örnekler. Kültürümüzde Türkü Sempozyumu 22-25 Ekim 2011, Sivas 